\title{
Target-Specific IPSC Kinetics Promote Temporal Processing in Auditory Parallel Pathways
}

\author{
Ruili Xie ${ }^{1}$ and Paul B. Manis ${ }^{1,2}$ \\ Departments of ${ }^{1}$ Otolaryngology/Head and Neck Surgery and ${ }^{2}$ Cell and Molecular Physiology, The University of North Carolina at Chapel Hill, Chapel Hill, \\ North Carolina 27599-7070
}

The acoustic environment contains biologically relevant information on timescales from microseconds to tens of seconds. The auditory brainstem nuclei process this temporal information through parallel pathways that originate in the cochlear nucleus from different classes of cells. Although the roles of ion channels and excitatory synapses in temporal processing have been well studied, the contribution of inhibition is less well understood. Here, we show in CBA/CaJ mice that the two major projection neurons of the ventral cochlear nucleus, the bushy and T-stellate cells, receive glycinergic inhibition with different synaptic conductance time courses. Bushy cells, which provide precisely timed spike trains used in sound localization and pitch identification, receive slow inhibitory inputs. In contrast, T-stellate cells, which encode slower envelope information, receive inhibition that is eightfold faster. Both types of inhibition improved the precision of spike timing but engage different cellular mechanisms and operate on different timescales. Computer models reveal that slow IPSCs in bushy cells can improve spike timing on the scale of tens of microseconds. Although fast and slow IPSCs in T-stellate cells improve spike timing on the scale of milliseconds, only fast IPSCs can enhance the detection of narrowband acoustic signals in a complex background. Our results suggest that target-specific IPSC kinetics are critical for the segregated parallel processing of temporal information from the sensory environment.

\section{Introduction}

The sensory environment contains multiple streams of information that must be efficiently processed and categorized by the CNS. Temporal information in particular is not represented on the sensory surface directly and must be processed by central mechanisms. Parallel central pathways often handle different aspects of temporal information. In the auditory system, acoustic information spans an extremely wide range of timescales, from microseconds to tens of seconds (Joris et al., 1994; Ulanovsky et al., 2004). The parallelization of auditory information processing begins with the segregation of synaptic connections from the auditory nerve (AN) onto the projection neurons in the cochlear nucleus (CN) (Cant and Benson, 2003).

Two cell classes, the bushy and T-stellate cells of the ventral $\mathrm{CN}(\mathrm{VCN})$, are the origins of major afferent fiber tracts innervating higher auditory structures. Bushy cells encode precise temporal information that can be used for azimuthal sound localization (Joris and Yin, 2007) and pitch identification (Shofner, 2008) and can fire spikes that report the phase of sound waves with a precision of tens of microseconds (Joris et al., 1994). In contrast,

Received May 26, 2012; revised Nov. 6, 2012; accepted Nov. 14, 2012.

Author contributions: R.X. and P.B.M. designed research; R.X. and P.B.M. performed research; R.X. and P.B.M. analyzed data; R.X. and P.B.M. wrote the paper.

This work was supported by National Institute on Deafness and Other Communication Disorders Grant R01DC004551. We thank J. Mancilla, B. Philpot, P. Kanold and two anonymous reviewers for comments on this manuscript and $\mathrm{H} . \mathrm{O}^{\prime}$ Donohue for experimental and organizational support.

The authors declare no competing financial interests.

Correspondence should be addressed to Dr. Paul B. Manis, G127 Physician's Office Building, CB 7070, 170 Manning Drive, Chapel Hill, NC 27599-7070. E-mail: pmanis@med.unc.edu.

DOI:10.1523/JNEUROSCI.2541-12.2013

Copyright $\odot 2013$ the authors $\quad 0270-6474 / 13 / 331598-17 \$ 15.00 / 0$
T-stellate cells discard such fine structure and instead encode slower temporal features, such as the sound envelope, on a millisecond timescale (Rhode and Greenberg, 1994; Wang and Sachs, 1994). Envelope cues are used for grouping sounds across frequency channels (Wang and Sachs, 1994, 1995; Elhilali et al., 2009) and are important in processing speech (Shannon et al., 1995; Swaminathan and Heinz, 2012). A constellation of mechanisms differentiates bushy and T-stellate cells, including the sizes and convergence of their excitatory synapses from the AN (Spirou et al., 2005; Cao and Oertel, 2010) and their intrinsic excitability and ion channel expression (Oertel, 1983; Rothman and Manis, 2003a). However, little is known about the role that inhibitory inputs play in these two cell types. Bushy and T-stellate cells both receive extensive glycinergic inhibition (Altschuler et al., 1986; Caspary et al., 1994; Gai and Carney, 2008) from two sources, the narrowly tuned tuberculoventral (TBV) cells of the dorsal CN (DCN) (Wickesberg and Oertel, 1990; Saint Marie et al., 1991) and the broadly tuned D-stellate cells of the VCN (Smith and Rhode, 1989; Arnott et al., 2004) (see Fig. 1A). Indirect evidence suggested that glycinergic inhibition to bushy and T-stellate cells could have different time courses (Harty and Manis, 1996), raising questions about the contribution of IPSC kinetics to differential neural processing in these two cell types.

We found that bushy and T-stellate cells receive inhibition with target-specific IPSC kinetics that support temporal processing on different timescales. Surprisingly, we found that the finely tuned temporal processing of bushy cells is improved by a slow glycinergic inhibition that limits spike initiation to the strongest and fastest excitatory inputs. In contrast, the slower temporal processing of T-stellate cells uses exceptionally fast glycinergic 
inhibition to transiently terminate poorly timed firing. We then used computer models to show how the time courses of inhibition play essential roles in different aspects of temporal processing in both cell types. We conclude that the time course of inhibition plays a crucial role in the analysis of the temporal information in acoustic signals.

\section{Materials and Methods}

All experiments were performed in accordance with protocols approved by the Institutional Animal Care and Use Committee at the University of North Carolina at Chapel Hill.

\section{Brain slice preparation}

Parasagittal brain slices (350 $\mu \mathrm{m}$ in thickness) containing all three regions of the $\mathrm{CN}$ [anteroventral $\mathrm{CN}$ (AVCN), posteroventral $\mathrm{CN}$ (PVCN), and DCN] were prepared from CBA/CaJ mice of either sex (aged postnatal days 29-39). Mice were anesthetized with a mixture of ketamine $(80 \mathrm{mg} / \mathrm{kg})$ and xylazine $(8 \mathrm{mg} / \mathrm{kg})$ and decapitated, and the brainstem was removed and immediately immersed into artificial CSF (ACSF), which was prewarmed to $34^{\circ} \mathrm{C}$ and bubbled with $5 \% \mathrm{CO}_{2}$ and $95 \% \mathrm{O}_{2}$. The ACSF contained the following (in $\mathrm{mm}$ ): $122 \mathrm{NaCl}, 3 \mathrm{KCl}$, $1.25 \mathrm{NaH}_{2} \mathrm{PO}_{4}, 25 \mathrm{NaHCO}_{3}, 20$ glucose, 3 myo-inositol, 2 sodium pyruvate, 0.4 ascorbic acid, $2.5 \mathrm{CaCl}_{2}$, and $1.5 \mathrm{MgSO}_{4}$. The brainstem was divided at the midline, each side was trimmed to a small block, and parasagittal slices were cut with a Vibratome 1000 (Technical Products). Slices were incubated in $\mathrm{ACSF}$ at $34^{\circ} \mathrm{C}$ for 30 min before they were transferred to a temperature-controlled $\left(34^{\circ} \mathrm{C}\right)$ submersion chamber on fixed-stage microscope (FS2; Carl Zeiss) for electrophysiological recordings. ACSF constantly flowed through the chamber at $3 \mathrm{ml} / \mathrm{min}$ during the recording session. Cells were visualized with $40 \times$ water-immersion objective.

\section{Electrophysiological recordings}

Standard whole-cell patch-clamp recording techniques were used in the experiments. Patch pipettes were pulled from borosilicate glass (KG-33; King Precision Glass) with a Sutter P2000 puller (Sutter Instruments). Voltage-clamp recordings were made with Cs-based internal solution containing the following (in mM): $105 \mathrm{CsMetSO}_{3}, 35 \mathrm{CsCl}, 5 \mathrm{EGTA}, 10$ HEPES, 4 magnesium ATP, 0.3 Tris-GTP, 10 Tris-phosphocreatine, and 3 QX-314, pH set to 7.2 with $\mathrm{CsOH}$. Whole-cell access resistance was $<15 \mathrm{M} \Omega$ and was compensated $>75 \%$ online. Cells were held at $-70 \mathrm{mV}$ for all voltage-clamp recordings. For current-clamp recordings, the potassium-based internal solution contained the following (in $\mathrm{mm}$ ): $126 \mathrm{~K}^{+}$-gluconate, $6 \mathrm{KCl}, 2 \mathrm{NaCl}, 10 \mathrm{HEPES}, 0.2 \mathrm{EGTA}, 4$ magnesium ATP, 0.3 Tris-GTP, and 10 Tris-phosphocreatine, $\mathrm{pH}$ set to 7.2 with $\mathrm{KOH}$. The concentrations of drugs used were as follows: $50 \mu \mathrm{M} \mathrm{APV}$, $5 \mu \mathrm{M}$ CNQX, $10 \mu \mathrm{M}$ SR95531 [2-(3-carboxypropyl)-3-amino-6-(4methoxyphenyl)pyridazinium bromide], $0.5 \mu \mathrm{M}$ TTX, and $0.5 \mu \mathrm{M}$ strychnine ( $2 \mu \mathrm{M}$ strychnine for EPSC data in Fig. 3A only). SR95531 and/or TTX were only applied in some spontaneous IPSC (sIPSC) recordings. All recordings were made with a Multiclamp 700B amplifier (Molecular Devices) under control of custom-written program in MATLAB (MathWorks).

A $75-\mu$ m-diameter concentric stimulating electrode (FHC) was placed on the AN root to evoke both excitatory and inhibitory responses in both bushy and T-stellate cells. To generate inhibition without contaminating AN excitation and to obtain more reliable inhibitory responses, in some experiments, an additional stimulating electrode was placed in the DCN. The DCN stimuli were delayed by 2 ms relative to AN stimuli. The duration of each electrical stimulus was $100 \mu \mathrm{s}$, and its strength was adjusted to 1.1-1.4 times the threshold.

\section{Cell identification}

Alexa Fluor 488 (Invitrogen) was added in the internal solution to visualize the cellular morphology online. Bushy cells have short dendrites that are heavily branched, whereas T-stellate cells have long and smooth dendrites that are less branched and orient on a plane that parallels the isofrequency sheets formed by the fascicles of AN fibers. When a $\mathrm{K}^{+}$gluconate-based internal was used, the cell type was also confirmed by examining the firing patterns to depolarizing current pulses. Bushy cells fire phasically to positive current injections, whereas T-stellate cells fire regular trains of action potentials (see Fig. 1C,D) (Wu and Oertel, 1984). D-Stellate cells were identified morphologically by their long smooth dendrites that cross the fascicles of AN fibers, as well as by their regular firing pattern and the fast and prominent sag produced by $I_{\mathrm{h}}$ in response to hyperpolarizing pulses (Fujino and Oertel, 2001). They were excluded from this study.

\section{Data analyses}

sIPSCs were detected and measured with a custom program in MATLAB using a scaled-template method (Clements and Bekkers, 1997). The decay phase of the averaged sIPSCs was fit with a single-exponential (for T-stellate cells) or a double-exponential (for bushy cells) function with Igor Pro (Wavemetrics). EPSCs were best fit with either single- or double-exponential function. The weighted decay time constant of PSCs with double-exponential fitting were calculated as follows: $\tau_{\mathrm{w}}=\tau_{\text {fast }} \times$ $A_{\text {fast }}+\tau_{\text {slow }} \times A_{\text {slow }}$, where $A_{\text {fast }}$ and $A_{\text {slow }}$ are the normalized amplitude of each component and $A_{\text {fast }}+A_{\text {slow }}=1$. Peak-scaled nonstationary noise analysis (Traynelis et al., 1993) for sIPSCs was performed with MiniAnalysis Program (Synaptosoft). For this analysis, sIPSC traces were first digitally low-pass filtered at $3 \mathrm{kHz}$. Candidate events were detected automatically using fixed threshold and then manually curated to remove contaminating overlapping events and events arising from false triggering by noise. The analysis was only performed in cells with at least 150 events (average of $455 \pm 83$ events, $n=18$ ). For current-clamp recordings, the spike timing was measured as the latency from the onset of the stimulation to the peak of each spike. The membrane time constant was estimated by fitting hyperpolarizing traces driven by small negative current injections from onset to the negative peak with exponential curves. Input resistance was calculated from the slope of the currentvoltage relationship for small hyperpolarizing currents.

\section{Computational models}

To test hypotheses about the functional significance of glycine receptor kinetics in the different classes of VCN neurons, we constructed two computational models. Although both models included the detailed biophysics of ion channels expressed in the VCN neurons, they differed in their purpose and overall design.

Overview of model 1 . The first model was designed specifically to help understand the experimentally observed relationship, shown in Figures 5 and 6 , between the time course of inhibition and the precision of spike timing in the bushy and stellate cells. This model is modified from a previous model (Spirou et al., 2005). The model consisted of several sequential stages.

(1) Spikes are triggered in the presynaptic axon, represented by a Hodgkin-Huxley model (adjusted to a temperature of $37^{\circ} \mathrm{C}$ assuming a $Q_{10}$ of 3.0), by direct current injection. For comparison with experimental data, trains of 50 stimulus pulses were delivered at either 100 or $400 \mathrm{~Hz}$.

(2) Each action potential produces a state change in the equations describing synaptic facilitation and depression (Dittman et al., 2000) and thus determines the probability of transmitter release at any given moment. To estimate the parameters for the synapses in the VCN, the rapid, non-summating portion of EPSC or IPSC amplitudes for 50, 100, 200, and $400 \mathrm{~Hz}$ stimulus trains and recovery times were measured for individual cells (see Fig. $8 A 1, A 2, C 1, C 2$ ) and were fit against this kinetic scheme. The full dataset for each cell, representing responses to different frequencies and the recovery time courses, were all fit at one time (MATLAB function fmincon). Receptor desensitization was not included in this step, because it was modeled as part of the postsynaptic receptor mechanism. The fitting parameters were averaged from fits to individual cells and were applied uniformly to all synapses associated with a given parent terminal. The fit parameters are shown in Table 1 for each cell type and synaptic input.

(3) Multiple steps in the synaptic release process are stochastic (Ribrault et al., 2011). Thus, at each synapse within the terminal, the instantaneous release probability calculated from step 2 is compared with a uniform random number draw to determine whether or not release occurs in response to an action potential. 
Table 1. Synaptic dynamics

\begin{tabular}{lcccc}
\hline Parameter & Bushy EPSC & Stellate EPSC & Bushy IPSC & Stellate IPSC \\
\hline$F_{\mathrm{l}}$ & 0.294 & 0.434 & 0.185 & 0.231 \\
$K_{0}$ & 0.523 & 0.672 & 2.30 & 1.234 \\
$k_{\max }$ & 19.3 & 52.8 & 27.7 & 45.4 \\
$K_{\mathrm{d}}$ & 0.113 & 0.0821 & 0.123 & 0.0118 \\
$K_{\mathrm{s}}$ & 11.5 & 14.3 & 8.85 & 17.9 \\
$k_{\mathrm{f}}$ & 17.8 & 18.2 & 5.71 & 19.1 \\
$\tau_{\mathrm{d}}$ & 15.2 & 3.98 & 0.124 & 98.1 \\
$\tau_{\mathrm{s}}$ & 17912 & 16917 & 9.60 & 17614 \\
$\tau_{\mathrm{f}}$ & 9.75 & 11.38 & 0.378 & 32.3 \\
$\Delta D$ & 0.578 & 2.47 & 4.00 & 2.52 \\
$\Delta F$ & 0.604 & 1.45 & 0.726 & 2.33 \\
Glu & 2.13 & 5.87 & 5.62 & 3.07 \\
\hline
\end{tabular}

Kinetic parameters correspond to variables as described by Dittman et al. (2000), their Table 1. F1, Resting release probability; Glu, peak concentration of glutamate during release. Parameters are the averages of fits to bushy and stellate cell data such as that shown in Figure $8, A 1, A 2, C_{1}$, and C2. Bushy cell IPSCs are for $100 \mathrm{~Hz}$ stimulus trains without recovery. All other datasets include $50,100,200$, and $400 \mathrm{~Hz}$ stimulation with $1-2 \mathrm{~s}$ recovery. $\tau$ values are in milliseconds.

(4) Individual quanta are not released synchronously at the end bulb of Held (Isaacson and Walmsley, 1995). Given that the end bulb terminal has multiple synaptic sites, asynchrony of release could influence the timing of action potential initiation on a timescale of tens of microseconds and thus could be an important factor in the spike timing precision of bushy cells. Thus, we incorporated a release latency distribution estimated from Isaacson and Walmsley (1995), their Figure 5D (extracted with Igor Pro, version 6.22). The data points were fit to a log-normal distribution, $\left[P(t)=\frac{1}{\sigma t \sqrt{2 \pi}} e^{\frac{(\operatorname{In} t-\mu)^{2}}{2 \sigma^{2}}}\right]$, with $\sigma=0.050 \mathrm{~ms}$ at the beginning of the trains, and increasing with an exponential time course $(\tau=$ $35.9 \mathrm{~ms})$ to $\sim 0.10 \mathrm{~ms}$ at the end of a 50 pulse train. The mean release latency, $\mu$, also increased, from 0.844 to $0.949 \mathrm{~ms}$ across the same trains, with a time constant of $21.6 \mathrm{~ms}$ at $400 \mathrm{~Hz}$. Thus, an asymptotic exponential latency shift of $100 \mu \mathrm{s}$ was also included in the model. Although the simulations of end bulb of Held input to bushy cells include this stochastic release mechanism, subsequent analysis showed that neither the variable release latency nor a variable release amplitude was necessary to observe the main effect of inhibition in the bushy cells. The stellate cell models did not include variable release latency.

(5) Each release event generates a single brief transient of transmitter in the model. Because the time course of the transmitter concentration is not easily measured experimentally, it was estimated from a stepwise curve-fitting process. First, an approximate time course of the transmitter concentration was determined by fitting the observed EPSC or IPSC time course to a rectangular pulse of transmitter, using the postsynaptic receptor kinetic models described below. The rectangular pulse was then replaced with a smooth function (Eq. 1), and the model was fit against the EPSC or IPSC time course while allowing the transmitter time course, but not the amplitude or receptor kinetics, to vary. In a final step, the synaptic current time course was fit against averaged data with the additional free parameters in the receptor models, as described below.

$$
[\mathrm{Glu}](t)=A \times\left(1.0-e^{-t\left(t_{g} / 3\right)}\right) \times e^{-t / \tau_{g}},
$$

For EPSCs, the time course of glutamate in the cleft was represented by Equation 1, where $\tau_{g}$ determines the kinetics of the glutamate pulse, and $A$ is the peak transmitter concentration (in millimolar). For IPSCs, we represented the time course of the glycine concentration in the synaptic cleft with a two-stage process:

$$
[\mathrm{Gly}]_{\text {vesicle }} \stackrel{k_{v}}{\rightarrow}[\mathrm{Gly}]_{\text {cleft }} \stackrel{k_{u}}{\rightarrow}[\mathrm{Gly}]_{\text {uptake }},
$$

with $k_{v}=531 \mathrm{~ms}^{-1}, k_{u}=4.17 \mathrm{~ms}^{-1}$, and $X_{\max }=0.731 \mathrm{~mm}$ for stellate cells. For bushy cells, $k_{v}=4 \times 10^{9} \mathrm{~ms}^{-1}, k_{u}=4.46 \mathrm{~ms}^{-1}$, and $X_{\max }=$ $0.737 \mathrm{~mm}$ ( $X_{\max }$ is a scaling term for the cleft transmitter concentration). Consistent with the role of the glycine transporters GLYT1 and GLYT2 in retrieving glycine from the cleft (Betz et al., 2006), the uptake term is
Table 2. AMPA receptor model kinetic parameters

\begin{tabular}{lllc}
\hline Parameter & Original & Bushy & Stellate \\
\hline$R_{o 1}$ & 100 & 107.9 & 39.3 \\
$R_{02}$ & 2 & 0.619 & 4.4 \\
$R_{c 1}$ & 2 & 3.68 & 0.667 \\
$R_{c 2}$ & 0.25 & 0.321 & 237 \\
$\tau_{g}$ & 0.1 & 0.25 \\
$A$ & 0.77 & 1.567 \\
\hline AMPA receptor kinetic values obtained by fitting the model of Raman and Trussell (1992) to measured EPSCs in the \\
mouse VCN. $\tau$ values are in milliseconds; $R$ values are in 1/millisecond.
\end{tabular}

Table 3. EPSC and IPSC kinetic parameters

\begin{tabular}{lllcl}
\hline Parameter & Bushy EPSC & Stellate EPSC & Bushy IPSC & Stellate IPSC \\
\hline$\tau_{\mathrm{r}}$ & 0.253 & 0.190 & 0.499 & 0.173 \\
$\tau_{\mathrm{f}}$ & 0.160 & 1.073 & 1.269 & 0.966 \\
$\tau_{\mathrm{s}}$ & 0.765 & 3.308 & 11.240 & 3.568 \\
$F$ & 0.984 & 0.917 & 0.682 & 0.912 \\
$N$ & 3 & 3 & 4 & 3 \\
\hline
\end{tabular}

EPSC and IPSC parameters obtained from fits of Equation 3 to measured EPSCS and IPSCs. $\tau$ values are in milliseconds; $n$ values are the number of cells measured.

absorbing. The kinetic model is driven with $[\mathrm{Gly}]_{\text {vesicle }}$ as a Dirac (instantaneous) pulse for each release event. The resulting time courses are shown in Figure 8, B2 and D2 (bottom traces in each panel). Although these are plausible representations for the transmitter concentration time course in the cleft, they are neither directly experimentally constrained, nor are they entirely independent of the receptor model. Nonetheless, the resulting model postsynaptic currents accurately reflect the time course of measured EPSCs and IPSCs in the target cells. To mimic the variability of quantal size, the concentration of transmitter associated with each release event was chosen from a Gaussian distribution with a mean estimated from the fitting above, and a coefficient of variation of 0.3 .

(6) The transmitter pulse then drives kinetic state models of the postsynaptic receptors. For EPSCs, a detailed state model of AMPA receptors postsynaptic to AN terminals on bushy neurons of the nucleus magnocellularis of the chicken (Raman and Trussell, 1992) was adapted for this study. These neurons are homologous to mammalian bushy cells, and they have very similar synaptic conductances (Gardner et al., 2001). The time course of the receptor model was adjusted to match that of mouse bushy cells, by allowing the opening and closing rates, $R_{o 1}, R_{o 2}, R_{c 1}$, and $R_{c 2}$, of the model to vary [see Table 2 ; all other parameters remained as described (Raman and Trussell, 1992)], with an assumed $Q_{10}$ of 1.5 (Spirou et al., 2005). To prevent the model parameters from falling into local minima caused by noise, the model was fit against an empirical equation that describes the time course of averaged EPSCs measured in bushy and stellate cells:

$I(t)=I_{\mathrm{DC}}+A \times\left(1-e^{-t / \tau_{r}}\right)^{n} \times\left[F \times e^{-t / \tau f}+(1-F)\right.$

$$
\times e^{-t / \tau_{S}}
$$

where $\tau_{\mathrm{r}}$ is the time constant for the rising exponential, $n$ represents ligand binding cooperativity (for the simulations run here, $n=2$ ), $\tau_{\mathrm{f}}$ is the fast decay time constant for the EPSC, $\tau_{\mathrm{s}}$ is the slow decay time constant, $F$ determines the fraction of fast versus slow decay, and $A$ is the amplitude of the EPSC. The parameters of these EPSC kinetic fits to Equation 3 are given in Table 3 . The peak open conductance of the receptors in this model varies with the "cleft" glutamate concentration and was $\sim 5 \%$ of the total conductance of the available channels with 1-3 mu glutamate.

AN synapses in the mouse also have NMDA receptors (Cao and Oertel, 2010). NMDA receptors were represented by a state model (Kampa et al., 2004), with the desensitization kinetic parameters $R_{\mathrm{d} 1}$ set to $0.1 \mathrm{~ms}^{-1}$ and $R_{\mathrm{d} 2}$ set to $10^{-4} \mathrm{~ms}^{-1}$. The rate constants in the model were originally measured at $23^{\circ} \mathrm{C}$, so each rate constant was scaled assuming a $Q_{10}$ of 2.0 (Korinek et al., 2010). These receptors were driven by the same glutamate transients as the AMPA receptors. Based on data from CBA P17 bushy 
Table 4. Glycine receptor model parameters

\begin{tabular}{lclr}
\hline Parameter (Gly6S) & Bushy & Parameter (GlyPL) & \multicolumn{1}{c}{ Stellate } \\
\hline$R_{\mathrm{d}}$ & $1.178 \mathrm{~ms}^{-1}$ & $a_{1}$ & $1.00 \mathrm{~ms}^{-1}$ \\
$R_{\mathrm{r}}$ & $0.00005 \mathrm{~ms}^{-1}$ & $a_{2}$ & $0.138 \mathrm{~ms}^{-1}$ \\
$R_{\mathrm{b}}$ & $0.00940 \mathrm{~mm}^{-1} \mathrm{~ms}^{-1}$ & $b_{1}$ & $1.700 \mathrm{~ms}^{-1}$ \\
$R_{\mathrm{u} 2}$ & $0.000086 \mathrm{~ms}^{-1}$ & $b_{2}$ & $8.051 \mathrm{~ms}^{-1}$ \\
$R_{o 1}$ & $0.188 \mathrm{~ms}^{-1}$ & $k_{\text {on }}$ & $0.0386 \mathrm{~ms}^{-1}$ \\
$R_{o 2}$ & $1.064 \mathrm{~ms}^{-1}$ & $k_{\text {off }}$ & $13.14 \mathrm{~ms}^{-1}$ \\
$R_{\mathrm{u} 1}$ & $0.0287 \mathrm{~ms}^{-1}$ & $R$ & $0.843 \mathrm{~ms}^{-1}$ \\
$R_{\mathrm{c} 1}$ & $0.104 \mathrm{~ms}^{-1}$ & $D$ & $12.82 \mathrm{~ms}^{-1}$ \\
$R_{\mathrm{c} 2}$ & 1.731 & & \\
\hline
\end{tabular}

Parameters for the two models representing glycine receptor kinetics in bushy and stellate cells. The parameters correspond to the state transitions for each model in Figure 8.

cells (Cao and Oertel, 2010), the NMDA to total current ratio at $+40 \mathrm{mV}$ was 0.3 , whereas for T-stellate cells, it was 0.53 . These correspond to NMDA/AMPA conductance ratios at $+40 \mathrm{mV}$ of 0.43 and 1.13, respectively.

For IPSCs, the kinetics were determined by fitting Equation 3 to IPSCs from individual cells (Table 3). Bushy cell IPSCs have a significant slow decay time constant (see Results) and a slower rise time, whereas stellate cell IPSCs are dominated by a fast decay time constant. The representative postsynaptic time courses were then evaluated against several state models of glycine receptors. A six-state model (see Fig. 8B2, Gly6S) provided the best fit for IPSCs in bushy cells (Table 4), with the exception of a slight deviation of the current immediately after the peak of the IPSC. A different kinetic scheme (Legendre, 1998) provided the best fit for IPSCs in stellate cells (see Fig. 8D2, GlyPL; Table 4). Although these models are based on experimental measurements of receptor kinetics and include features such as receptor desensitization and multiple open states, they are not intended to be mechanistically comprehensive.

All synaptic conductances in the model were scaled to account for peak receptor open probability, to allow direct comparisons with experimentally measured conductances.

7) The single-compartment postsynaptic cell models were adapted from our previous work (Rothman and Manis, 2003a,b,c), after scaling of the rates to $34^{\circ} \mathrm{C}$ as described previously (Rothman and Manis, 2003c). Bushy cells were based on the type II model (Rothman and Manis, 2003c). We adjusted the magnitudes of the high-threshold $\mathrm{K}^{+}$conductance $(58 \mathrm{nS})$, low-threshold $\mathrm{K}^{+}$conductance $(80 \mathrm{nS})$, the hyperpolarization activated current $(30 \mathrm{nS})$, and the total capacitance $(26 \mathrm{pF})$ to match the mean values measured in mouse (Cao and Oertel, 2010). The sodium channel was replaced with a model of wild-type $\mathrm{NaV}_{1.1}$ channels from Barela et al. (2006). The response of the modified model to current injection is plotted in Figure $8 E$ and shows the same phasic firing pattern, voltage-dependent rectification, and time-dependent voltage sag with hyperpolarization as seen with mouse, guinea pig, and rat bushy cells (Oertel, 1983; Manis and Marx, 1991; Francis and Manis, 2000).

The T-stellate cells were based on the type I model (Rothman and Manis, 2003c). We adjusted the conductances to reflect the properties of mouse T-stellate cells (Rodrigues and Oertel, 2006; Oertel et al., 2011). The sodium channel was changed to wild-type $\mathrm{NaV}_{1.1}$ (Barela et al., 2006), with a conductance of $800 \mathrm{nS}$ and the activation voltage shifted positive by $4.3 \mathrm{mV}$. The conductance of the high-threshold $\mathrm{K}^{+}$channels $(250 \mathrm{nS})$, the hyperpolarization-activated current conductance (18 nS), and the leak current $(8.0 \mathrm{nS})$ established an input resistance of $74 \mathrm{M} \Omega$. The total cell capacitance was set to $25 \mathrm{pF}$. This model (Fig. $8 F$ ) fires with regular trains of action potentials, similar to mouse T-stellate cells in vitro, achieving a sustained firing rate of nearly $400 \mathrm{~Hz}$ at $1 \mathrm{nA}$. Inhibitory interneurons (representing either D-stellate cells or DCN TBV cells) were created using the type II-I model (Rothman and Manis, 2003c).

Structure of model cells, synapses, and network. To complete the model, a simple deterministic network was assembled from synapses and model cells to mimic the known circuit of the $\mathrm{CN}$. The patterns of convergence, strengths of the connections, and network delays for this network are listed in Table 5. The strengths of some of the synaptic connections were explored parametrically as shown in Figure 9. For the simulations of the effect of inhibition on bushy cells, the inhibitory inputs were discon-
Table 5. Network model convergence and synaptic conductances

\begin{tabular}{llll}
\hline & Bushy cell & T-Stellate cell & D-Stellate cell \\
\hline AN fibers $(n)$ & 2 & $5^{b}$ & 10 \\
Synaptic sites/fiber $(n)$ & $90^{a}$ & 5 & 5 \\
AMPA $R$ conductance & $40-70 \mathrm{nS}$ & $2-10 \mathrm{nS}$ & 5 \\
Inhibitory inputs $(n)$ & 10 & 8 & $\mathrm{~N} / \mathrm{A}$ \\
Synapses/inhibitory fiber $(n)$ & 10 & 5 & - \\
Glycine $R$ conductance & $0-40 \mathrm{~ns}$ & $0-200 \mathrm{nS}$ & - \\
Network delay from AN & $0 \mathrm{~ms}$ & $0 \mathrm{~ms}$ & $0.3 \mathrm{~ms}$ \\
Release $\sigma$ from AN & $0.05 \mathrm{~ms}$ & $0.05 \mathrm{~ms}$ & $0.05 \mathrm{~ms}$ \\
Release $\sigma$ from inhibition & $0.2 \mathrm{~ms}$ & $0.2 \mathrm{~ms}$ & $\mathrm{~N} / \mathrm{A}$ \\
\hline
\end{tabular}

${ }^{a}$ Wang and Manis (2005)

${ }^{b}$ Ferragamo et al. (1998)

nected from the AN and stimulated directly, to reflect the experimental situation.

The model was constructed using NEURON (version 7.2) and controlled by Python (versions 2.6, 2.7) scripts. Fitting of models to data to determine the specific parameters used a mixture of Python (numpy and scipy from www.scipy.org and OpenOpt from www.openopt.org) scripts, embedded NEURON (version 7.2) models, and MATLAB routines.

Overview of model 2. The second model was developed to test the importance of the IPSC time course in a network-based computation of comodulation masking release (CMR), based on the model from Pressnitzer et al. (2001), with a number of specific differences. Biophysically realistic neurons from Rothman and Manis (2003c) were used to represent the different cells types. Given that the effects of inhibition shown in model 1 did not depend on either stochastic release of single quanta or on variability in quantal size, a simple $\alpha$ function was used to represent the postsynaptic conductance. Simulated AN fiber spike trains were generated for multiple acoustic stimuli using the auditory periphery model of Zilany et al. (2009). For each set of acoustic stimulus waveforms, we generated responses to 50 stimulus repetitions for each of 50 AN fibers, with characteristic frequencies varying from one-fourth of the stimulus center frequency $(4.0 \mathrm{kHz})$ to four times the center frequency (e.g., $1-16$ $\mathrm{kHz})$.

The acoustic stimulus sets were designed as described by Grose and Hall (1989) and consisted of an on-frequency masker, an on-frequency signal, and flanking bands that were absent [reference (REF) condition], comodulated with the on-frequency masker [comodulated (CM) condition], or modulated with different phases such that the flanking bands spanned the unit circle in phase [codeviant (CD) condition]. The sound level of the on-frequency masker was varied (signal/masker ratio) when measuring signal detectability. Spike trains were generated using the settings for low-threshold (high spontaneous rate) AN fibers, and the onfrequency and off-frequency masker stimuli were set to $35 \mathrm{~dB}$ SPL; the signal stimulus level was adjusted relative to the on-frequency masker (signal/masker ratio). Simulations using midthreshold AN fibers with the same set of acoustic stimuli showed results similar to simulations using low-threshold fibers.

The network model, implemented in the simulation package Brian (Goodman and Brette, 2009), contained of population of target cells (either T-stellate or bushy cells), innervated by a subpopulation of AN fibers at $4 \mathrm{kHz}$ (see Fig. 10D). T-Stellate cells used the type $\mathrm{I}_{\mathrm{C}}$ model (Rothman and Manis, 2003c), whereas D-stellate cells used the type I-II model, which included a small amount of low-threshold conductance. Bushy cells were modeled with the standard type II parameters. The on-characteristic frequency $(4 \mathrm{kHz})$ AN fibers were connected with a probability of 0.2 with $4.5 \mathrm{nS}$ synapses to a bank of $25 \mathrm{~T}$-stellate cells (average convergence, 5 AN fibers/T-stellate cell) or with a probability of 0.1 with $22 \mathrm{nS}$ synapses to a bank of 25 bushy cells (average convergence, 2.5 AN fibers/bushy cell). Each D-stellate cell received input from $25 \%$ of the AN fibers with $4.5 \mathrm{nS}$ synapses, but the inputs spanned the full range of frequencies $(1-16 \mathrm{kHz})$. The $50 \mathrm{D}$-stellate cells in turn converged with a probability of 0.2 onto the T-stellate or 0.1 onto bushy cells. The weights of D-stellate cells were adjusted with a space constant of 0.1 (D-stellate connections to the target cells were 
therefore somewhat local), with a maximum conductance of $7.5 \mathrm{nS}$. There were no explicit delays built into the network. Because each cell is driven by different sets of AN fibers or inhibitory neurons, there is asynchrony in the arrival of EPSPs and IPSPs that likely would make small delays have an undetectable effect. Nonetheless, we confirmed that introducing additional delays of $0-4 \mathrm{~ms}$ in the inhibition onto bushy or T-stellate cells had no significant effect on the CMR detection. The specific connections in the network were assigned randomly, using the above connection patterns as a template, and differed for each run of the model. Consequently, the results depend not on the fine structure of the network architecture but instead rather on the overall pattern of connectivity within the network. Responses to each stimulus condition were run four times with different detailed connection patterns, and the results are plotted as the mean \pm SD from these runs. Spike times were captured from each of the target cells in the network; thus, the histograms and signal detectability results for each run are computed from the spike patterns of 25 target cells.

The synapses from the D-stellate to T-stellate cells were described by an $\alpha$ function conductance with a time constant of $1.3 \mathrm{~ms}$, whereas $\mathrm{D}$-stellate to bushy cell synapses were described by an $\alpha$ function with a time constant of $11 \mathrm{~ms}$, consistent with our experimental results. The effect of changing this time constant was also parametrically explored in the model. When comparing the effects of different IPSC time courses, the amplitude of the $\alpha$ function was normalized according to the time constant, so that the integral of the current (i.e., the total charge associated with a synaptic event) remained constant. With this adjustment, the target cells fired in response to the stimuli at approximately the same rate independent of the time course of inhibition.

The difference in responses to the various stimulus conditions was assessed using a $d^{\prime}$ measure, following a previous analyses (Pressnitzer et al., 2001). Briefly, for each stimulus condition, the mean spike rate and variance were computed across the 25 target cells in 20 ms wide bins. For each bin, $i$, a value of $d_{i}$ was computed as follows:

$$
d_{i}=\sqrt{\frac{2 \times\left(R A_{i}-R B_{i}\right)^{2}}{\sigma_{A_{i}}^{2}+\sigma_{B_{i}}^{2}}},
$$

where $R A_{i}$ is the mean spike rate for response with the signal plus masker in time bin $i, R B_{i}$ is the mean rate for the response for the masker alone in time bin $i$, and $\sigma^{2}{ }_{A i}$ and $\sigma_{B i}^{2}$ are the variances of the spike counts in the corresponding stimulus conditions for the $i$ th bin. $d^{\prime}$ was then computed as the root mean square value of $d_{i}$ across all time bins (e.g., across the entire response). The base value for $d^{\prime}$, when the stimulus was weak relative to the masker, could have a mean value $>0$ because the spike rates often were slightly different for the two conditions.

\section{Statistical analyses}

All statistical analyses were performed with Prism (GraphPad Software). Significant differences were detected using two-tailed Student's $t$ test, unpaired unless otherwise stated. Multiple groups were compared with a one-way ANOVA, followed by Tukey's post hoc tests. Data were presented as mean \pm SEM throughout, except for modeling results in Figures 10 and 11 , which show mean \pm SD.

\section{Results}

\section{Glycinergic IPSCs are slow in bushy cells and fast in} T-stellate cells

We measured the time course of glycinergic IPSCs in bushy and T-stellate cells in parasagittal brain slices of mouse CN (Fig. 1). Evoked IPSCs (eIPSCs) were elicited by stimulating the TBV cells in the DCN (Fig. 1A,B), while blocking glutamatergic transmission with CNQX and APV. Cells were held at $-70 \mathrm{mV}$ for all voltage-clamp recordings. eIPSCs in bushy cells had dramatically slower decay times than those in T-stellate cells. The decay phase of the eIPSCs in bushy cells was best fit with a double-exponential function (Fig. 1E), with a fast time constant of $3.69 \pm 0.18 \mathrm{~ms}$ (normalized amplitude, $49.2 \pm 2.3 \%$ ) and a slow time constant of $17.81 \pm 1.05 \mathrm{~ms}$ (normalized amplitude, $50.8 \pm 2.3 \%)(n=31$ cells; weighted decay time constant, $\left.\tau_{\mathrm{w}}=11.12 \pm 0.78 \mathrm{~ms}\right)$. In contrast, the decay of the eIPSCs in T-stellate cells was best fit with a single-exponential function with a time constant of $1.23 \pm$ 0.08 ms (Fig. $1 F, n=26$ cells; $t_{(55)}=11.5, p<0.001$ compared with bushy cells). There was no significant difference between the amplitudes of eIPSCs in bushy cells $(-554.2 \pm 149.8 \mathrm{pA}, n=31)$ and in T-stellate cells $(-521.0 \pm 92.4 \mathrm{pA}, n=26)\left(t_{(55)}=0.18\right.$, $p=0.86)$. eIPSCs in both cell types were completely blocked by $500 \mathrm{~nm}$ strychnine (Fig. $1 E, F$ ), indicating that they are mediated by glycine receptors. We conclude that bushy and T-stellate cells receive target-specific glycinergic inhibition with distinct kinetics from TBV cells in the DCN.

To test whether all glycinergic IPSCs onto bushy cells and T-stellate cells differ in their kinetics, we measured the time course of sIPSCs. The time course of sIPSCs in bushy and T-stellate cells was similar to that of their eIPSCs (Fig. $1 G-K$ ). The decay phase of bushy cell sIPSCs was best fit with a doubleexponential function $\left(\tau_{\text {fast }}=3.08 \pm 0.21 \mathrm{~ms}\right.$; normalized amplitude, $47.4 \pm 2.0 \% ; \tau_{\text {slow }}=13.94 \pm 1.03 \mathrm{~ms}$; normalized amplitude, $52.6 \pm 2.0 \% ; n=32$; weighted $\tau_{\mathrm{w}}=8.75 \pm 0.63 \mathrm{~ms}$; Fig. $1 I$ ), whereas the decay of T-stellate cell sIPSCs was best fit with a single-exponential function $(\tau=1.06 \pm 0.06 \mathrm{~ms}, n=27)$. The decay of sIPSCs in bushy cells was significantly slower than that of T-stellate cells (Fig. $1 J ; t_{(57)}=11.2, p<0.001$ ). Although T-stellate cells had a slightly higher average sIPSC frequency than bushy cells (bushy, $1.25 \pm 0.18 \mathrm{~Hz}, n=32$; T-stellate, $1.99 \pm 0.34$ $\mathrm{Hz}, n=27)$, the difference did not reach significance $\left(t_{(57)}=\right.$ 1.99, $p=0.052)$. There was no difference in sIPSC amplitudes (bushy, $-113.3 \pm 8.0 \mathrm{pA}, n=32$; T-stellate, $-99.3 \pm 7.4 \mathrm{pA}, n=$ $\left.27 ; t_{(57)}=1.30, p=0.20\right)$. Furthermore, there was no overlap in decay time constants between the two cell types when individual events were pooled across cells (Fig. $1 K$ ), suggesting that the IPSC shape represents a categorical distinction between cell types and is not specific to the TBV inputs. The large (eightfold) difference in IPSC time course most likely depends on postsynaptic mechanisms and specifically on the glycine receptor subunit composition.

Because different glycine receptor subtypes can have different distributions of single-channel conductances (Wässle et al., 2009), we estimated the mean single channel conductance from sIPSCs using peak-scaled nonstationary noise analysis (Hartveit and Veruki, 2007) (Fig. 2). In bushy cells, the estimated singlechannel conductance was $28.9 \pm 3.9 \mathrm{pS}(n=9)$, whereas in T-stellate cells it was $44.8 \pm 4.9 \mathrm{pS}(n=9)\left(t_{(16)}=2.54, p=\right.$ 0.022 ). Together, the electrophysiological data demonstrate that bushy and T-stellate cells express functionally different glycine receptor subtypes.

\section{Both bushy and T-stellate cells receive fast EPSCs}

The target-specific differences in IPSC kinetics indicate that glycinergic inhibition might influence signal processing in bushy and T-stellate cells in different ways. Because neural computation relies on both excitatory and inhibitory inputs, in addition to voltage-gated membrane conductances, we next measured the time course of EPSCs within each cell type and directly compared with that of IPSCs to explore how IPSCs might interact with EPSCs during synaptic processing.

We recorded EPSCs from both bushy and T-stellate cells in the high-frequency region of AVCN (Fig. 1A) in the presence of strychnine to block IPSCs. The mean decay time constant of sEPSCs in bushy cells was $0.22 \pm 0.01 \mathrm{~ms}(n=27)$, whereas that 

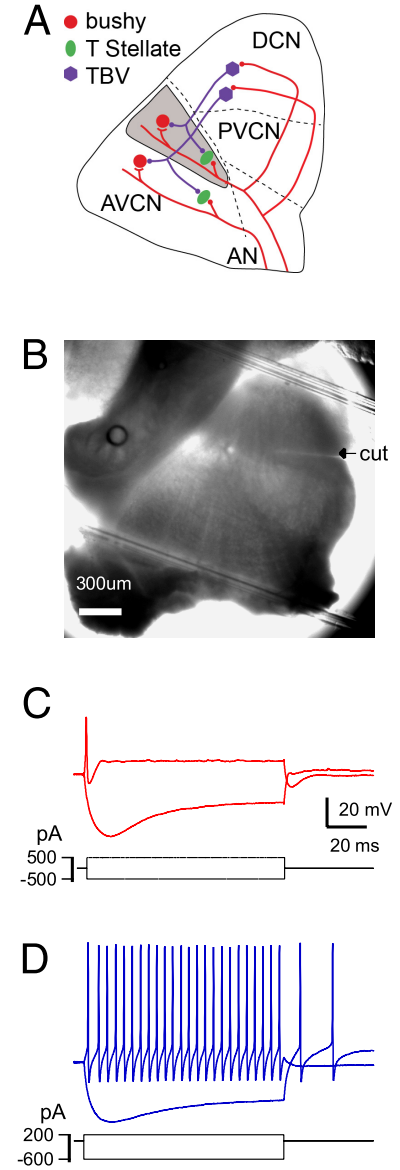
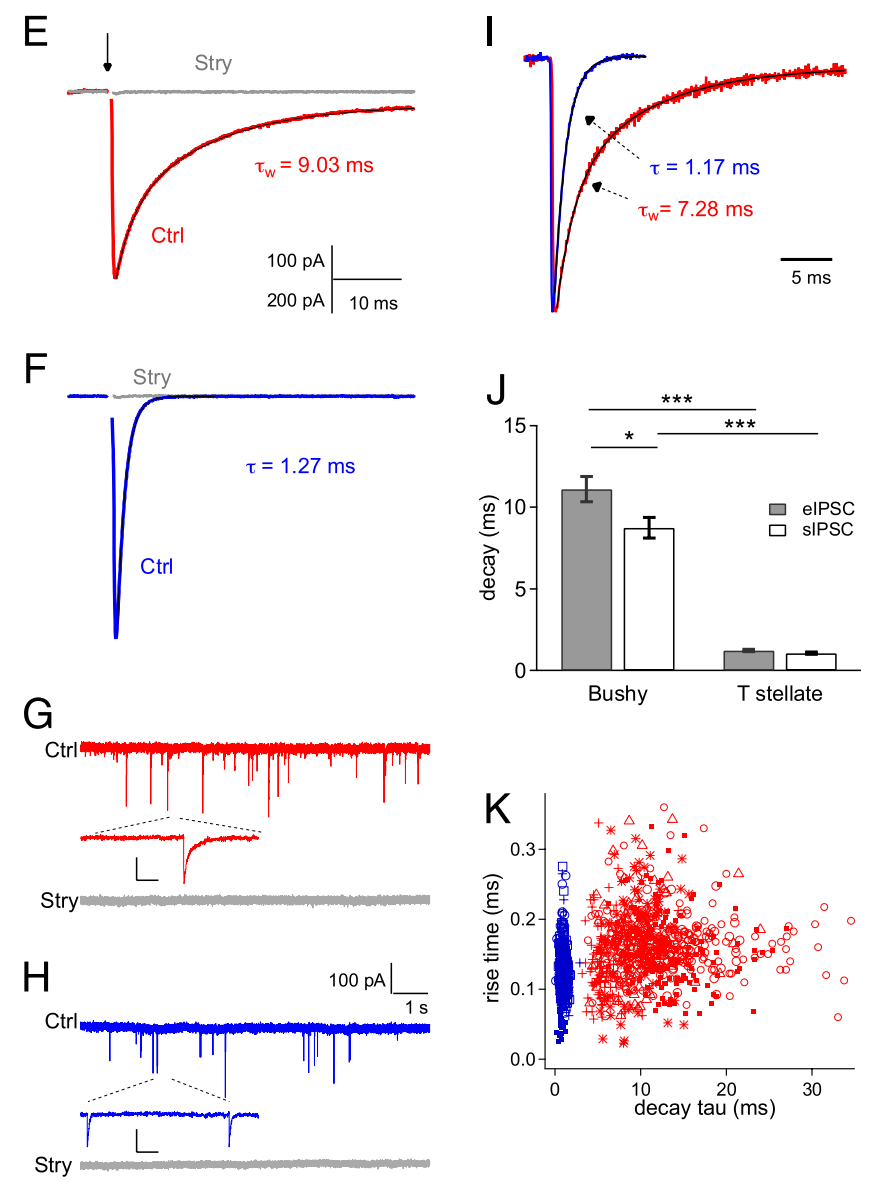

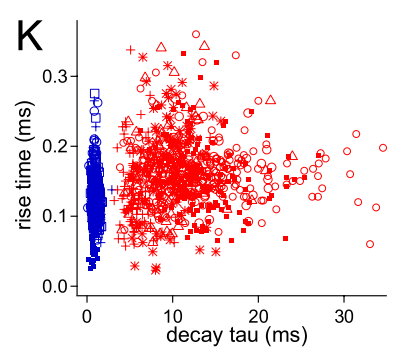

Figure 1. Glycinergic IPSCS show different decay time courses in bushy and T-stellate cells. $A$, Diagram of the CN circuit. Red, AN fibers (excitatory); blue, TBV tract (inhibitory); gray area, high-frequency region of AVCN. $\boldsymbol{B}$, Image of a parasagittal CN slice. A cut between PVCN and DCN prevents antidromic stimulation of AN fibers. $\boldsymbol{C}, \boldsymbol{D}$, Typical current-clamp responses of bushy $(\boldsymbol{C})$ and T-stellate $(\boldsymbol{D})$ cells. $\boldsymbol{E}$, elPSCs in bushy cells (red) were blocked by strychnine (gray). Black line, Double-exponential fit to decay $\left(\tau_{\mathrm{w}}\right.$ is weighted time constant; see Materials and Methods). $\boldsymbol{F}$, elPSC of a T-stellate cell (blue) was blocked by strychnine (gray) and was fit with a single exponential (black). Traces in $\boldsymbol{E}$ and $\boldsymbol{F}$ are average of 60 responses. $\boldsymbol{G}, \boldsymbol{H}$, sIPSCs from bushy (red) and T-stellate (blue) cells were blocked by strychnine (gray; all traces in the presence of APV, CNQX, and TTX). Strychnine block of elPSCs and sIPSCs was observed in 11 of 11 bushy cells and 10 of 10 T-stellate cells. Calibration in inset: 100 pA, 20 ms. I, Averaged sIPSCs from the cell in $\boldsymbol{G}$ (red, 923 events) and (H) (blue, 791 events), normalized to peak. Black traces, Fits of averaged bushy (red) and T-stellate (blue) sIPSCs with double and single exponentials, respectively. J, elPSC and sIPSC decay kinetics are similar within, but different between, cell types. Unpaired $t$ test: ${ }^{*} p<0.05,{ }^{* * *} p<0.001$. $\boldsymbol{K}$, Kinetics of single sIPSCs pooled from four T-stellate (blue, 1454 events) and six bushy (red, 744 events) cells. Different symbols represent different cells. Ctrl, Control; Stry, strychnine.
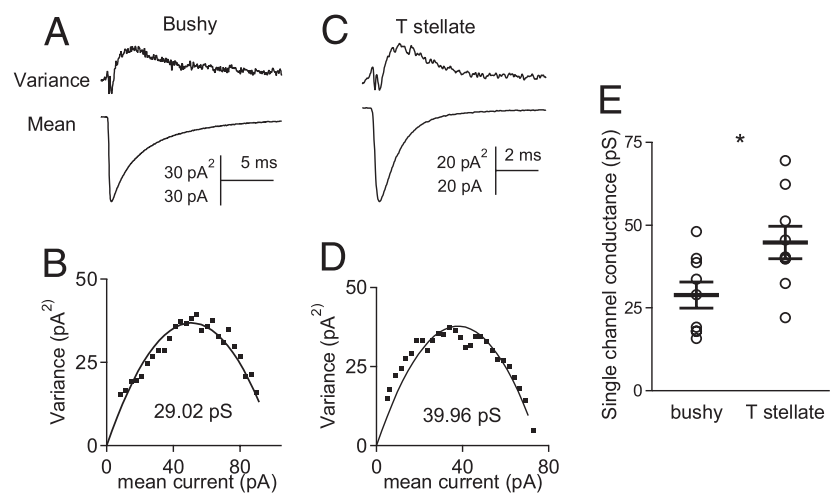

Figure 2. Glycine receptors in bushy and T-stellate cells have different single-channel conductances. $\boldsymbol{A}$, Mean current and ensemble variance of 539 sIPSC events from a bushy cell. $\boldsymbol{B}$, The variance-mean current plot from the cell in $A$ was described by a parabolic curve, from which the mean single-channel conductance of the glycine receptors was estimated. C, D, Analysis of 461 sIPSC events from a T-stellate cell as in $\boldsymbol{A}$ and $\boldsymbol{B}$. $\boldsymbol{E}$, Summary of single-channel conductances in both cell types. Estimation of single-channel conductance was based on the driving force of 50 $\mathrm{mV}$ for chloride. in T-stellate cells was $0.62 \pm 0.11 \mathrm{~ms}(n=8)\left(t_{(33)}=6.91, p<\right.$ $0.001)$. AN eEPSCs had decay time constants of $0.34 \pm 0.02 \mathrm{~ms}$ $(n=25)$ in bushy cells and $1.10 \pm 0.12 \mathrm{~ms}(n=8)\left(t_{(31)}=10.5\right.$, $p<0.001)$ in T-stellate cells. Both bushy and T-stellate cells receive fast EPSCs, consistent with previous studies (Gardner et al., 2001; Cao and Oertel, 2010). However, there is a sharp contrast between the time courses of EPSCs and IPSCs within each cell type. Glycinergic sIPSCs were 40 times slower than the sEPSCs in bushy cells, whereas sIPSCs were only slightly slower than sEPSCs in T-stellate cells (Fig. 3).

It is unlikely that the slow IPSCs in bushy cells transiently interact with submillisecond EPSCs on a one-on-one basis. Instead, the slower glycinergic inhibition in bushy cells may tonically adjust the engagement of voltage-gated ion channels and thus indirectly modulate spike timing. In contrast, the kinetics of IPSCs in T-stellate cells is comparable with that of their EPSCs. This makes it possible for inhibition to interact temporally with rapid acoustically driven fluctuations in excitation. The short 2 ms delay between AN eEPSPs and the appearance of IPSPs (Wickesberg and Oertel, 1990) (see also Fig. $6 C)$, attributable to one additional synapse in the inhibitory circuit (Fig. 1A) further supports this possibility. 
A
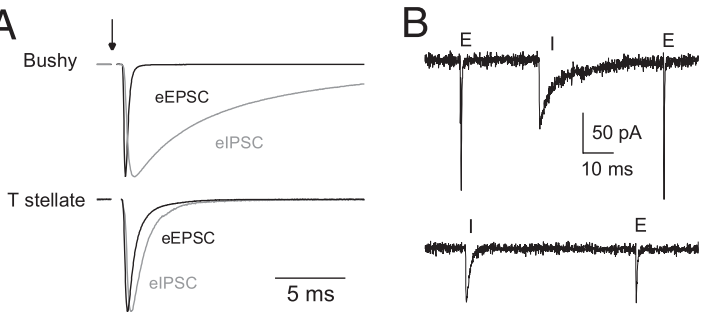

Figure 3. Comparison of IPSC versus EPSC kinetics. A, elPSCs and eEPSCs from two example bushy cells (top) and two T-stellate cells (bottom). Each trace is an average of 30-50 trials, normalized to the peak current. The arrow indicates the time of stimulation. The stimulus artifact was removed. $\boldsymbol{B}$, Example sIPSCs and sEPSCs obtained from an example bushy (top) and a T-stellate cell (bottom). The difference between EPSC and IPSC kinetics can be clearly seen in the same cells. E, sEPSC event; I, SIPSC event. No drugs were used to block excitatory or inhibitory receptors. Cs-based internal solution contained $35 \mathrm{~mm}$ chloride, so both EPSCs and IPSCs appear as inward currents.

\section{Inhibition summates more in bushy cells than in T-stellate cells}

The functional effect of inhibition not only depends on the kinetics of single IPSCs but also on the integrative properties of the postsynaptic neurons and on short-term synaptic dynamics. Both bushy and T-stellate cells receive high levels of synaptic drive in vivo. TBV and D-stellate neurons, the main sources of glycinergic input, can also fire at rates up to $400 \mathrm{~Hz}$ in response to sound (Young and Voigt, 1982; Rhode, 1999; Arnott et al., 2004). Because synapses can show short-term plasticity when driven at high rates, we next evaluated the contribution of glycinergic inhibition during repetitive stimulation. TBV cells in DCN (Fig. $1 \mathrm{~A}, B)$ were stimulated with 50-pulse trains at 100 and $400 \mathrm{~Hz}$, while glutamatergic transmission was blocked with APV and CNQX. In voltage clamp, the slow IPSCs in bushy cells summate at both 100 and $400 \mathrm{~Hz}$ and generate sustained inhibitory currents (Fig. 4A), despite depression of the individual IPSCs. We calculated a summation ratio as the average of the baseline current immediately before each IPSC to the peak IPSC over the last 40 pulses of the train (Fig. $4 A, B$ ), expressed as a percentage of the peak current. The IPSC summation ratio in bushy cells was $63.6 \pm 3.3 \%$ at $100 \mathrm{~Hz}(n=10)$ and $93.3 \pm$ $1.0 \%$ at $400 \mathrm{~Hz}(n=8)$. In contrast, fast IPSCs in T-stellate cells remain distinct at $100 \mathrm{~Hz}$, and the summation ratio was $2.3 \pm 0.5 \%(n=10)\left(t_{(18)}=18.1, p<0.001\right.$ compared with bushy cells), whereas at $400 \mathrm{~Hz}$ IPSCs partially overlapped and had a summation ratio of $44.3 \pm 3.8 \%(n=10)\left(t_{(16)}=11.3\right.$, $p<0.001$ compared with bushy cells).

We further tested the effect of inhibition in current-clamp recordings, because bushy and $\mathrm{T}$-stellate cells differ in intrinsic membrane properties. Bushy cells have significantly shorter membrane time constants than T-stellate cells (bushy, $1.49 \pm$ $0.05 \mathrm{~ms}, n=24$; T-stellate, $3.88 \pm 0.31 \mathrm{~ms}, n=21 ; t_{(43)}=8.19$, $p<0.001$ ) and have lower input resistances (bushy, 40.2 \pm 2.0 $\mathrm{M} \Omega, n=24$; T-stellate, $81.5 \pm 8.0 \mathrm{M} \Omega, n=21 ; t_{(43)}=5.31, p<$ 0.001). As shown in Figure 4, $C$ and $D, 100$ and $400 \mathrm{~Hz}$ trains generate slow IPSPs in bushy cells that summate to produce a constant hyperpolarization (IPSP summation ratio, $52.5 \pm 3.6 \%$ at $100 \mathrm{~Hz}, n=18 ; 96.6 \pm 0.4 \%$ at $400 \mathrm{~Hz}, n=17)$. In T-stellate cells, $100 \mathrm{~Hz}$ trains evoked well-isolated IPSPs with no sustained hyperpolarization during the train (summation ratio, $1.5 \pm$ $4.6 \%, n=9 ; t_{(25)}=8.42, p<0.001$ compared with bushy cells). At $400 \mathrm{~Hz}$, T-stellate cell IPSPs show significant summation $\left(87.4 \pm 1.8 \%, n=10 ; t_{(25)}=5.75, p<0.001\right.$ compared with bushy cells) that leads to a sustained hyperpolarization similar to that in bushy cells. Therefore, slow IPSPs in bushy cells convey little information about the timing of inhibitory inputs and generate tonic inhibition during repetitive activation, especially at high frequencies. In contrast, the fast IPSPs in T-stellate cells convey precise temporal information about presynaptic spikes, especially at lower frequencies.

\section{Glycinergic inhibition plays different roles for temporal processing in bushy and T-stellate cells}

Bushy cells and T-stellate cells are the origins of pathways that process different temporal aspects of the sound stimulus. Therefore, we next explored how the differences in time course of glycinergic inhibition contribute to these functional specifications by examining the temporal precision of spikes in bushy and T-stellate cells, with and without inhibition.

In bushy cells, AN stimulation alone did not reliably evoke identifiable IPSPs because IPSPs were often slow and small in amplitude. It is difficult to tell whether the lack of identifiable AN eIPSPs in bushy cells is attributable to disrupted inhibitory circuit during slicing. Therefore, inhibition was introduced by directly stimulating TBV cells in the DCN via a second stimulating electrode, with a 2 ms delay relative to AN stimulation, while the AN fibers were cut between PVCN and DCN (Fig. 1B). Spikes from the last 40 pulses (during which the response reached a steady state) of the 50-pulse train were analyzed. At $100 \mathrm{~Hz}$, glycinergic inhibition evoked by $\mathrm{DCN}$ stimulation failed to change the firing probability of bushy cells (AN stimulation alone, $0.98 \pm 0.02$; AN plus DCN stimulation, $0.97 \pm 0.02 ; n=8$ cells; paired $t$ test, $t_{(7)}=$ $1.78, p=0.12$ ). The spike latency, relative to the onset of AN stimulation, was also unchanged (Fig. $5 A-C$ ). The spike jitter, calculated as the SD of the spike latency, was similar without and with evoked inhibition (AN alone, $59 \pm 12 \mu \mathrm{s}$; AN plus DCN, $64 \pm 16 \mu \mathrm{s} ; n=8$ cells; paired $t$ test, $t_{(7)}=0.578, p=0.58$ ). Accordingly, there was no significant difference in the vector strength [a measure of the spike synchronization to a periodic stimulus (Goldberg and Brown, 1969)] of the firing between the two conditions (AN alone, $0.9991 \pm 0.0003$; AN plus DCN, $0.9988 \pm 0.0005 \mu \mathrm{s} ; n=8$ cells; paired $t$ test, $t_{(7)}=0.809, p=$ 0.45) (Fig. 5D).

However, at $400 \mathrm{~Hz}$, glycinergic inhibition significantly decreased the firing probability of bushy cells from $0.60 \pm 0.09$ spikes/stimulus (AN stimulation alone) to $0.26 \pm 0.09$ spikes/ stimulus (AN plus DCN stimulation) (Fig. $5 F-H, n=8$ cells; paired $t$ test, $\left.t_{(7)}=4.17, p=0.004\right)$. The spike latency was less variable with inhibition (Fig. 5G,H), and the spike jitter decreased from $144 \pm 15 \mu$ s (AN alone) to $107 \pm 10 \mu$ s (AN plus DCN $)\left(n=8\right.$; paired $t$ test, $\left.t_{(7)}=3.78, p=0.007\right)$. The vector strength of the firing increased significantly, from $0.933 \pm 0.012$ (AN alone) to $0.963 \pm 0.006$ (AN plus DCN) $(n=8$, Fig. $5 K$; paired $t$ test, $\left.t_{(7)}=3.50, p=0.010\right)$. Although this is a small but significant numerical improvement in vector strength, the nearly $30 \%$ decrease in spike jitter should greatly contribute to the precise coding of acoustic phase by bushy cells (Joris et al., 1994).

In contrast to bushy cells, AN stimulation alone reliably evoked EPSPs, spikes, and IPSPs in T-stellate cells (Fig. 6C), so that separate TBV stimulation was not necessary to activate inhibition. In these experiments, the role of inhibition was evaluated by comparing spike trains in the presence and absence of strychnine. At $100 \mathrm{~Hz}$, AN stimulation eEPSPs and spikes that were followed by IPSPs that prevented additional depolarization and additional spikes (Fig. $6 A-C$ ). When inhibition was blocked by strychnine, individual stimuli could evoke multiple spikes that arose from prolonged EPSPs. Consequently, the firing probabil- 

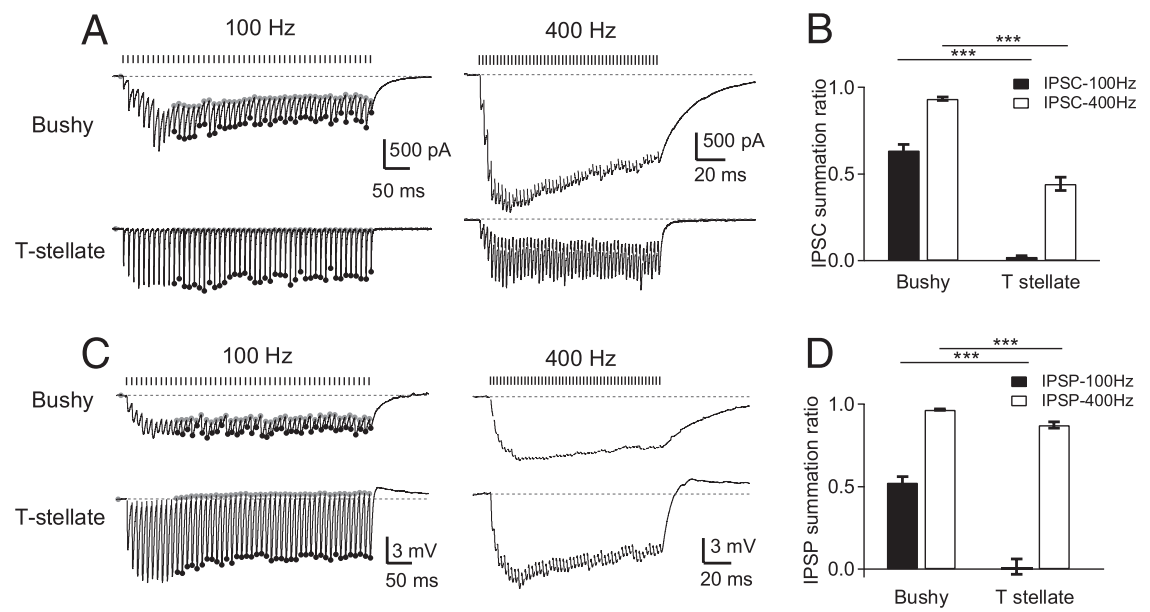

Figure 4. Glycinergic transmission during repetitive stimulations. A, Example elPSCs of a bushy and a T-stellate cell to 50-pulse stimulation at the DCN. Stimulus timing is indicated by tick marks above the traces. Dashed line, Baseline current; gray dot, IPSC "foot" current; black dot, IPSC peak current. The foot and peak IPSC are not labeled in $400 \mathrm{~Hz}$ traces for clarity. Cells were voltage clamped at $-70 \mathrm{mV}$. B, Average summation ratio (foot/peak IPSC size) of the last 40 IPSCs in bushy and T-stellate cells. $\boldsymbol{C}$, Current-clamp recordings of a bushy and a T-stellate cell to 50 -pulse stimulation. Dashed line, Resting membrane potential (bushy, $-54.8 \mathrm{mV}$; T-stellate, $-50.3 \mathrm{mV}$ ); gray dot, IPSP foot potential; black dot, IPSP peak potential. D, Average summation ratio (foot/peak IPSP size) of the last 40 IPSPs in bushy and T-stellate cells. Voltage-clamp recordings $(\boldsymbol{A}, \boldsymbol{B})$ used $\mathrm{CS}^{+}$-based internal solution with $35 \mathrm{mM} \mathrm{Cl}^{-}$; current-clamp recordings $(\boldsymbol{C}, \boldsymbol{D})$ used K ${ }^{+}$-based internal solution (see Materials and Methods). Traces in $\boldsymbol{A}$ and $\boldsymbol{C}$ are averages of between 5 and 20 repetitions. The stimulus artifacts were removed from all traces. All recordings were made in the presence of APV and CNQX. Unpaired $t$ test: ${ }^{* *} p<0.001$.

ity increased from $0.75 \pm 0.07$ spikes per stimulus in control to $1.43 \pm 0.12$ in strychnine $\left(n=15\right.$ cells; Fig. $6 G$; paired $t$ test, $t_{(14)}$ $=5.38, p<0.001)$. The extra spikes decreased the temporal precision of firing, and the vector strength fell from $0.89 \pm 0.04$ in control to $0.62 \pm 0.05$ in strychnine $(n=15$ cells; Fig. $6 F$; paired $t$ test, $\left.t_{(14)}=5.43, p<0.001\right)$. The spike jitter increased from $780 \pm 159 \mu$ s in control to $1673 \pm 165 \mu$ s with strychnine $(n=15$ cells; paired $t$ test, $\left.t_{(14)}=5.00, p<0.001\right)$. At $400 \mathrm{~Hz}($ Fig. $6 H-L)$, glycinergic inhibition onto T-stellate cells did not significantly change their firing probability (control, $0.89 \pm 0.08$; strychnine, $0.92 \pm 0.09 ; n=9$ cells; paired $t$ test, $\left.t_{(8)}=0.491, p=0.64\right)$, vector strength (control, $0.504 \pm 0.089$; strychnine, $0.396 \pm 0.075 ; n=9$ cells; paired $t$ test, $t_{(8)}=1.99, p=0.082$ ), or spike jitter (control, $595 \pm 84 \mu \mathrm{s}$; strychnine, $671 \pm 57 \mu \mathrm{s} ; n=9$ cells; paired $t$ test, $t_{(8)}=$ $0.873, p=0.41)$.

Because EPSCs recorded at $-70 \mathrm{mV}$ (Fig. 3; representing AMPA currents) are fast in both bushy and T-stellate cells, we next tested whether the prolonged EPSP in T-stellate cells had a contribution from NMDA receptors. Both APV and strychnine were applied after the recordings of T-stellate cells in strychnine alone (Fig. 6A,B). APV eliminated the delayed spikes and restored the temporal precision of firing at $100 \mathrm{~Hz}$. The vector strength was $0.96 \pm 0.02$ in control, decreased to $0.76 \pm 0.03$ with strychnine, and recovered to $0.97 \pm 0.01$ under both strychnine and APV $(n=6$ cells; Fig. $6 F$; repeatedmeasures ANOVA, $\left.F_{(2,5)}=31.6, p<0.001\right)$. Tukey's post hoc tests indicate a significant difference between the control and strychnine conditions $(p<0.001)$ and between the strychnine and strychnine plus APV conditions $(p<0.001)$, but there was no significant difference between the control and strychnine plus APV conditions $(p>0.05)$. The firing probability was $0.91 \pm 0.06$ in control, increased to $1.49 \pm 0.10$ with strychnine, and recovered to $1.00 \pm 0.01$ with both strychnine and $\operatorname{APV}\left(n=6\right.$; Fig. $6 G$; repeated-measures ANOVA, $F_{(2,5)}=$ $26.8, p<0.001)$. Tukey's post hoc tests indicate a significant difference in firing probability between the control and strychnine conditions $(p<0.001)$ and between the strychnine and strychnine plus APV conditions $(p<0.00)$, but there was no significant difference between the control and strychnine plus APV condition $(p>0.05)$. We conclude that activation of NMDA receptors in T-stellate cells prolongs the time course of AN-driven EPSPs (Cao and Oertel, 2010; Oertel et al., 2011), and this can be countered by the fast and well-timed glycinergic inhibition at low frequencies.

The effects of glycinergic inhibition on spike jitter show that, paradoxically, slow glycinergic inhibition promotes temporal encoding in bushy cells at a timescale of tens of microseconds, whereas fast inhibition in T-stellate cells improves spike timing at a much slower timescale of milliseconds.

\section{Inhibition affects spike threshold differently in two cell types}

The time course of inhibition can influence the gating of voltage-gated ion channels and thus influences the precision of firing in response to excitatory inputs. Therefore, we next explored how spike threshold was affected by inhibition in both bushy and T-stellate cells.

Bushy cells fire action potentials when the slope of a membrane potential depolarization exceeds a certain threshold (McGinley and Oertel, 2006). However, it is often difficult in bushy cells to distinguish the onset of the action potential from the fast rising phase of the EPSP. Therefore, to estimate threshold voltage for spike initiation, we calculated the maximum of the first derivative (Fig. 7A) of EPSPs that failed to trigger spikes during the last 40 responses to $400 \mathrm{~Hz}$ trains. The 90th percentile of the distribution of rising slopes of all EPSPs (as marked by arrows in Fig. $7 B$ ) was then taken as the lower bound of the threshold slope that triggers spikes. Measured in this way, the threshold slope was significantly higher in the presence of glycinergic inhibition $(54.6 \pm 5.8 \mathrm{mV} / \mathrm{ms})$ than without inhibition $(41.0 \pm 4.9 \mathrm{mV} / \mathrm{ms})$ during $400 \mathrm{~Hz}$ trains $(n=10$ cells; Fig. $7 C$; paired $t$ test, $\left.t_{(9)}=4.13, p=0.0033\right)$. In the presence of the slow inhibition, only the fastest-rising and largest EPSPs were able to initiate spikes, consistent with the effects of inhibition reported in vivo (Kuenzel et al., 2011). Because the EPSPs are composed of release events from multiple synaptic sites, those EPSPs with the most synchronous release will be most effective in generating spikes, and this will also increase the precision of spike timing.

We also examined the effect of inhibition on spike thresholds in T-stellate cells. The spike thresholds of T-stellate cells can be readily measured as the voltage at which the second derivative of the voltage is maximum during the rising phase of the EPSPspike complex (Fig. 7D). The first spike in response to each stimulus during the last 40 pulses of the $100 \mathrm{~Hz}$ trains was used to calculate the average spike threshold with (control) and without (strychnine) inhibition (Fig. 7E). As shown in Figure 7F, inhibition did not change the spike threshold of T-stellate cells (control, $-35.23 \pm 0.89 \mathrm{mV}$; strychnine, $-35.32 \pm 0.91 \mathrm{mV} ; n=15$ cells; paired $t$ test, $\left.t_{(14)}=0.350, p=0.73\right)$. This suggests that inhibition plays a different role in T-stellate cells than in the bushy cells. 

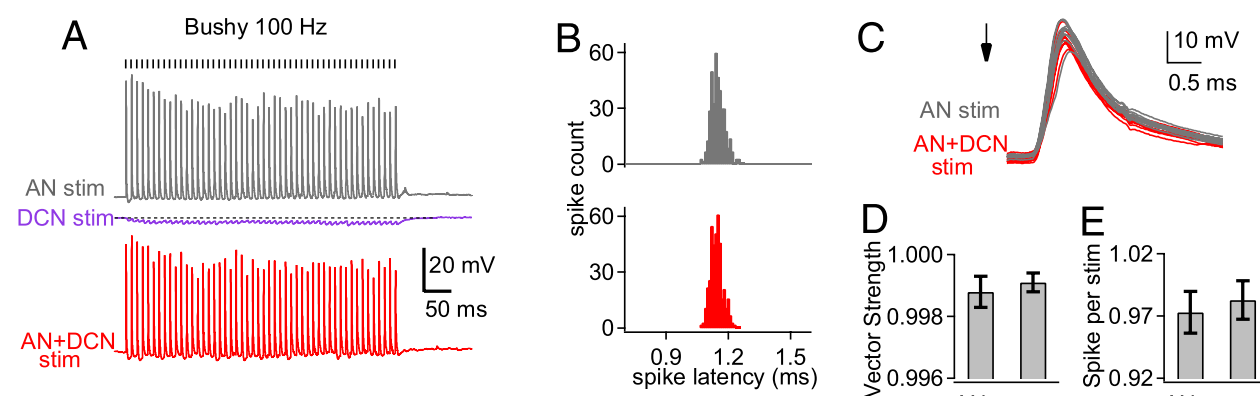

stim
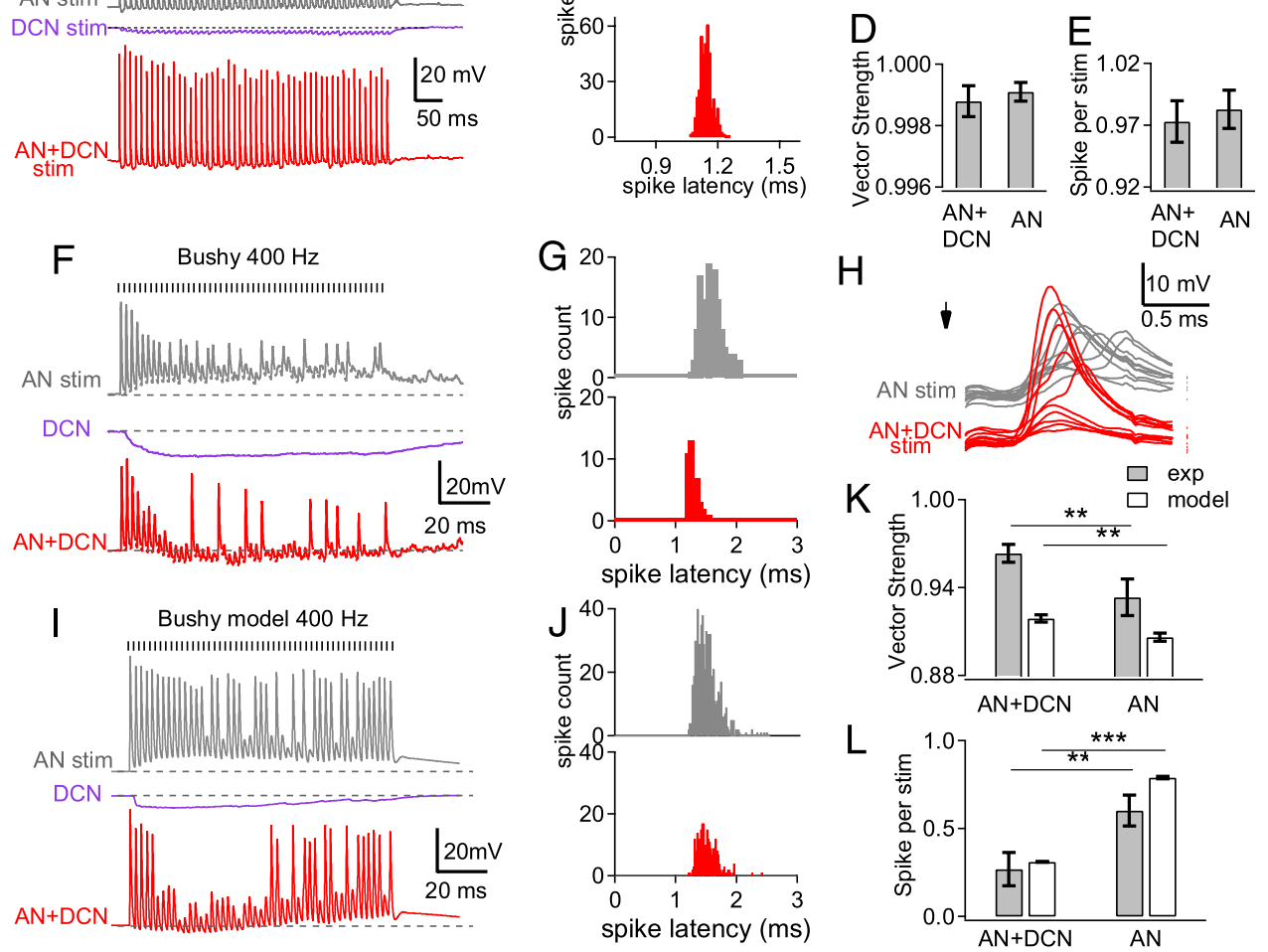

Figure 5. The role of glycinergic inhibition on temporal processing in bushy cells. $A$, Example responses of a bushy cell to $100 \mathrm{~Hz}$ stimulation at AN (excitation), DCN (inhibition), or both sites (excitation and inhibition) with DCN stimulation delayed $2 \mathrm{~ms}$ relative to AN. Stimulus onsets are indicated by the tick marks above the traces. The stimulus artifact was removed in all traces. $\boldsymbol{B}$, Folded period histogram of spike peak latency during the last 40 stimuli, compiled over 10 repetitions, from the cell in $A$. Inhibition did not improve spike timing. $C$, Expanded view of the individual responses during the train to show spike jitter with (red) and without (gray) DCN inhibition. D, Summary of changes in vector strength for eight bushy cells. $\boldsymbol{E}$, Summary of change in firing probability per stimulation. $\boldsymbol{F}$, Responses of the same bushy cell as in $\boldsymbol{A}$ to $400 \mathrm{~Hz}$ stimulation at AN (excitation), DCN (inhibition), or both sites (excitation and inhibition). Tick marks above traces show stimulus timing. $\boldsymbol{G}$, Folded period histogram of spike peak latency during the last 40 pulses of the trains from the cell in $\boldsymbol{F}$, summed over 10 repetitions of the stimulus train. Spike jitter was reduced with inhibition. $\boldsymbol{H}$, Example traces during the train to show spike jitter with (red) and without (gray) DCN inhibition. $\boldsymbol{I}, \boldsymbol{J}$, Responses of the bushy cell model to $400 \mathrm{~Hz}$ stimulation, in the same layout as in $F$ and $\mathbf{G} . \boldsymbol{K}$, Inhibition improved vector strength of bushy cells in both experimental study (gray; exp) and computer model simulations (white; model). Same labels apply in $\boldsymbol{L}$. $\boldsymbol{L}$, Inhibition decreased firing probability. Paired $t$ test: ${ }^{* *} p<0.01,{ }^{* * *} p<0.001$.

\section{Target-specific IPSC kinetics are essential for temporal processing}

To gain insight into how IPSCs with different time courses contribute to the fidelity of spike timing in bushy and T-stellate cells, we constructed computational models to simulate the physiology of both cell types. The models included AN inputs driving stochastic synapses with rate-dependent release dynamics (Fig. $8 A 1, A 2, C 1, C 2)$, postsynaptic receptors that matched the time course of measured EPSCs and IPSCs (Fig. 8B1,B2,D1,D2), and biophysically based spiking models of bushy and T-stellate neurons (Fig. $8 E-H$ ). The models thus captured the essential features of synaptic release, receptor kinetics for both excitation and inhibition, and the intrinsic postsynaptic excitability (for details about the model cells and network constructions, see Materials and Methods).

The excitatory and inhibitory conductance levels were systematically varied over a physiologically plausible range to evaluate the performance of the models. Twenty repetitions of response to 50-pulse stimulus trains were generated at each combination of excitation and inhibition. Each run used a different seed for the random number generator at each synaptic site and, thus, the timing and amplitude of release and the shapes of the EPSPs, vary from run to run. Postsynaptic spike probability and vector strength were measured over the last 40 responses in the 50-pulse train, exactly as in the experimental situation.

In the bushy cell model with slow inhibitory conductances, increasing excitation increases firing probability, whereas increasing inhibition systematically decreases the firing probability (Fig. 9A) for $400 \mathrm{~Hz}$ trains. For the weaker excitatory conductances $(40-60 \mathrm{nS})$, vector strength increases monotonically with increasing inhibition (Fig. 9B), whereas with stronger excitation $(65,70 \mathrm{nS})$, increasing inhibition has little effect. When we replaced the slow inhibitory conductances in the bushy cell model with the faster synaptic conductances seen in T-stellate cells, increasing inhibition had little effect on spike probability (Fig. 9C) or in improving spike timing (Fig. 9D). This difference between slow and fast IPSCs can be better appreciated when compared for a single excitatory conductance level (50 nS) (Fig. $9 E$, F, showing the mean \pm SEM of 10 runs for each combination). A two-way ANOVA showed that the IPSC time course and the inhibitory conductance level both influenced the vector strength $\left(F_{(8,162)}=\right.$ $6.24, p<0.0001)$, with the largest effect $\left(F_{(1,162)}=147.7, p<\right.$ $0.0001)$ revealing that the slow IPSCs resulted in higher vector strengths than the fast IPSCs. Bonferroni's post hoc tests revealed that the effect of IPSC time course was significant $(p<0.001)$ for all values of $g_{\mathrm{I}}>10 \mathrm{nS}$, including the combination of excitatory 

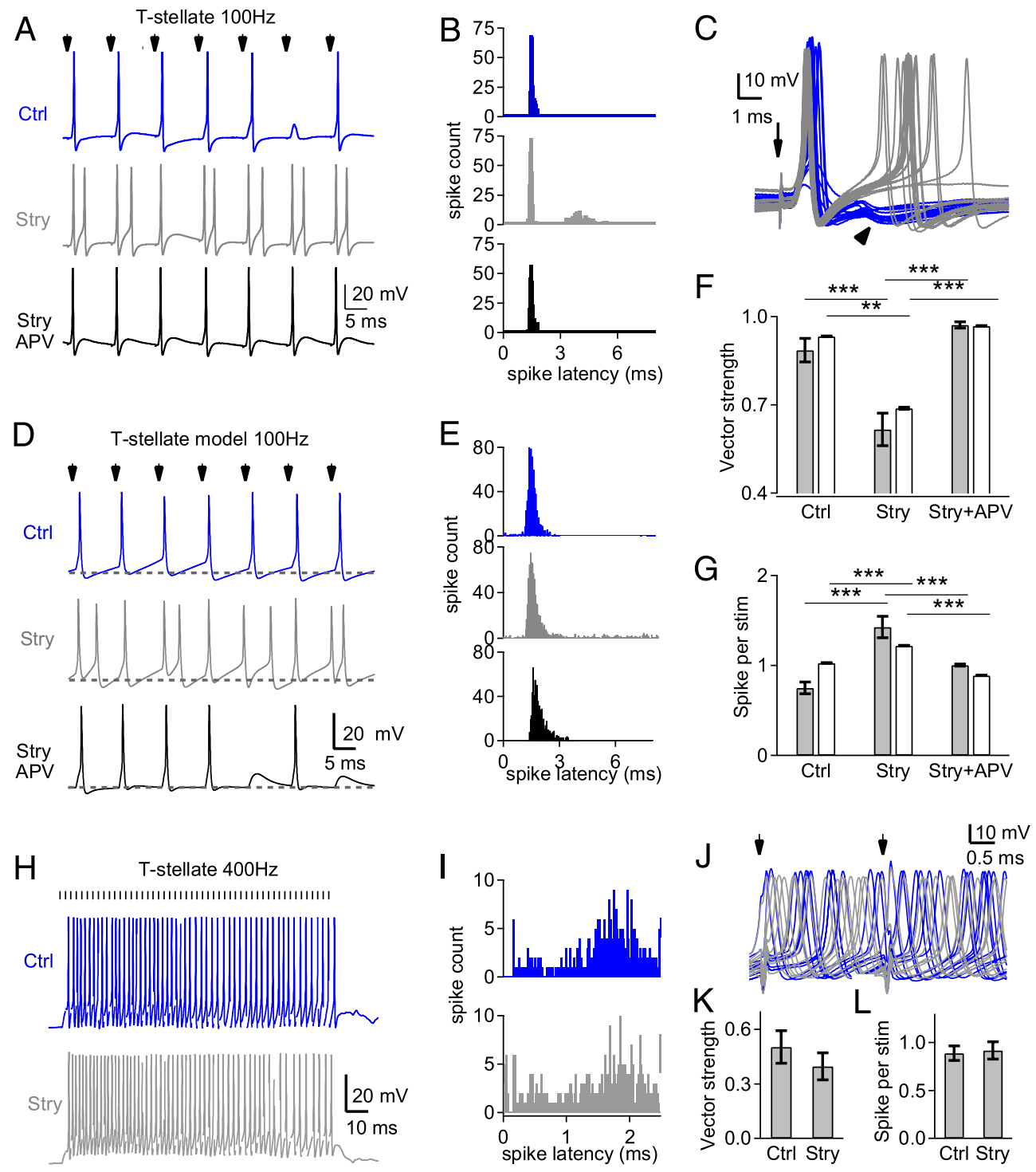

Figure 6. The role of glycinergic inhibition on temporal processing in T-stellate cells. A, Responses of a T-stellate cell to $100 \mathrm{~Hz}$ stimulation in control (blue), strychnine (gray), and strychnine plus APV (black). B, Folded period histogram of the spike peak latency. Data were from five 50-pulse trains under each condition. C, Example traces of a T-stellate cell during the train show that IPSPs in control (blue) prevented supernumerary spikes, as shown in gray, whereas inhibition was blocked by strychnine. IPSPs (arrowhead) were delayed by $\sim 2 \mathrm{~ms}$ relative to EPSPs. $\boldsymbol{D}, \boldsymbol{E}$, Responses of the T-stellate cell model to $100 \mathrm{~Hz}$ stimulation, in the same layout as in $\boldsymbol{A}$ and $\boldsymbol{B}$. $\boldsymbol{F}$, Blocking glycinergic inhibition decreased the vector strength of T-stellate cells, which was restored by additional block of NMDA-receptor-mediated currents. For experimental data: control (Ctrl) and strychnine (Stry), $n=15$; strychnine plus APV, $n=6$. For modeling data: $n=10$ runs in each group. $\mathbf{G}$, Blocking inhibition increased the firing probability, which was restored by additional block of NMDA-receptor-mediated currents. For experimental data: control and strychnine, $n=15$; strychnine plus APV, $n=6$. For modeling results: $n=10$ runs in each group. $\boldsymbol{H}$, Example responses of a T-stellate cell to $400 \mathrm{~Hz}$ stimulation under control (blue) or in the presence of strychnine (gray). $\boldsymbol{I}$, Folded period histogram of spike times from the last 40 stimuli, accumulated over 10 trains, under each condition. $\boldsymbol{J}$, Expanded view of individual responses of the T-stellate cell during the train. $\boldsymbol{K}$, Summary change in vector strength for nine T-stellate cells. $L$, Summary change in spikes per stimulus for the same T-stellate cells. ${ }^{* *} p<0.01,{ }^{* * *} p<0.001$.

and inhibitory conductances $\left(g_{\mathrm{E}}=50 \mathrm{nS}, g_{\mathrm{I}}=20 \mathrm{nS}\right)$ that matched the experimentally observed firing probabilities with and without inhibition (Fig. 5L). When the slow IPSCs were replaced with fast IPSCs $(\tau=1.3 \mathrm{~ms})$, no improvement in spike timing was seen for any IPSC strengths (Fig. $9 E, F$ ). Neither the variable release latency nor trial-to-trial variations in quantal size were necessary for these results in the model. These model results suggest that that slow glycinergic inhibition onto bushy cells helps to improve the temporal precision of spike timing to repeated synaptic inputs, whereas fast inhibition is unable to provide the same improvement.

We then performed a similar set of simulations for the T-stellate cell model, using $100 \mathrm{~Hz}$ stimulus trains. Here, increasing inhibition with fast kinetics decreases firing probability (Fig.
$9 G$ ) and improves vector strength primarily through the suppression of secondary spikes (Fig. 9H). The largest effects of inhibition occur when EPSCs are large and trigger multiple spikes per stimulus. When the fast inhibition $(\tau=1.3 \mathrm{~ms})$ was replaced with slow inhibition $(\tau=11 \mathrm{~ms})$, the same overall effects were visible, although the improvement in vector strength was not as large (Fig. 9I,J). A two-way ANOVA showed that both the IPSC time course and the inhibitory conductance level influenced the vector strength $\left(F_{(11,216)}=475.8, p<0.0001\right)$, with the largest total variance difference attributable to $g_{\mathrm{I}}\left(F_{(11,216)}=7454, p<\right.$ $0.0001)$, although the IPSC time course also had a significant effect $\left(F_{(11,216)}=17,426, p<0.0001\right)$. Bonferroni's post hoc tests revealed that there was a significant effect of IPSC time course $(p<0.001)$ for all values of $g_{\mathrm{I}}>20 \mathrm{nS}$, including for the combi- 

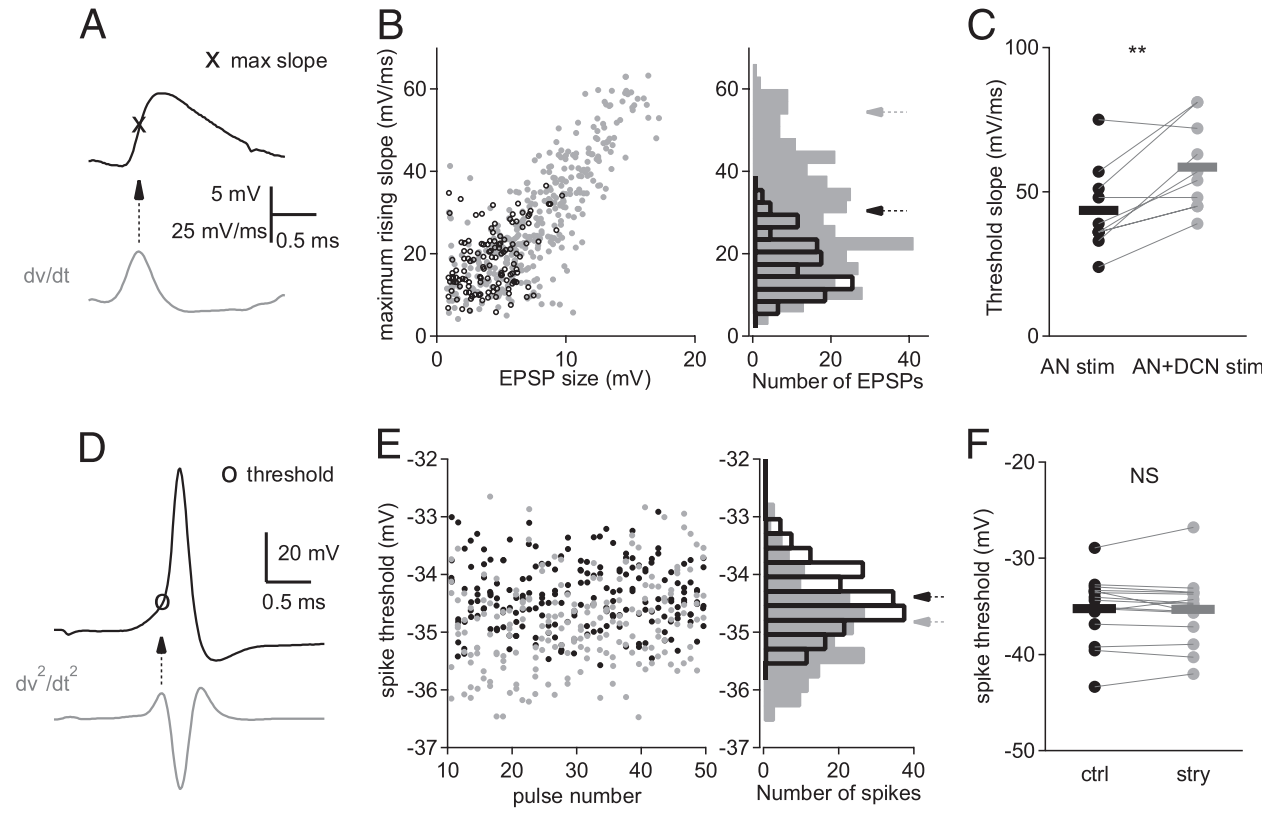

Figure 7. Fast and slow inhibition differentially affect spike thresholds. A, Maximum rising slope of an example EPSP from a bushy cell. Black, EPSP trace; gray, first derivative. $\boldsymbol{B}$, Inhibition increased the maximum rising slopes of EPSPs that failed to trigger spikes during $400 \mathrm{~Hz}$ trains in an example bushy cell. Left, Scatter plot of EPSPS; right, histogram showing the distribution of maximum rising slopes; gray, with glycinergic inhibition (AN $+D C N$ stim); black, without glycinergic inhibition (AN stim). Arrows indicate estimated threshold slope. C, Summary of threshold slopes from 10 bushy cells with and without inhibition. $\boldsymbol{D}$, Spike threshold of an example T-stellate cell. Black, spike trace; gray, second derivative. $\boldsymbol{E}$, Inhibition did not change the spike thresholds of an example T-stellate cell. Left, Scatter plot of spike threshold during the last 40 pulses of the train; right, histogram showing the distribution of spike thresholds; black, with inhibition [control (ctrl)]; gray, without inhibition [strychnine (stry)]. Arrows indicate average spike thresholds. $F$, Summary of average spike thresholds from 15 T-stellate cells.

nation of excitation and inhibition $\left(g_{\mathrm{E}}=8 \mathrm{nS}, g_{\mathrm{I}}=100 \mathrm{nS}\right)$ that led to firing probabilities in the presence and absence of inhibition that matched our experimental data (Fig. 6G). With fast inhibition ( $\tau=1.3 \mathrm{~ms}$ ) at $100 \mathrm{~Hz}$, a single spike was generated per stimulus cycle, and there was only one peak in the period histogram (Fig. 6D,E). In the absence of inhibition, the model cell showed prolonged depolarization and repeated spikes that decreased the spike timing precision. In agreement with experimental observations (Fig. $6 A-C$ ), removing both inhibition and NMDA currents shortened the EPSPs and reduced supernumerary spikes (Fig. $6 F, G$ ) (vector strength from modeling data in Fig. $6 F$ : control, $0.933 \pm 0.002$; strychnine, $0.688 \pm 0.004$; strychnine plus APV, $0.968 \pm 0.001 ; n=10$ runs in each group; repeatedmeasures ANOVA, $F_{(2,9)}=4290, p<0.001$ ) (firing probability from modeling data in Fig. $6 G$ : control, $1.027 \pm 0.008$; strychnine, $1.220 \pm 0.011$; strychnine plus APV, $0.887 \pm 0.005 ; n=10$ runs in each group; repeated-measures ANOVA, $F_{(2,9)}=4010$, $p<0.001$; Tukey's post hoc tests indicate $p<0.001$ for all pairwise comparisons). These results suggest that fast inhibition is somewhat more effective in improving spike timing in T-stellate cells, but it is not essential and leaves open the question of why T-stellate cells have such fast inhibitory conductances.

\section{Fast inhibition improves narrowband signal detection in T-stellate cells but not bushy cells}

CMR is a psychophysical phenomenon in which the detection of an on-frequency signal ("signal") in the presence of modulated on-frequency masker ("masker") is improved by adding offfrequency sounds ("sidebands") that are comodulated with the masker (Hall et al., 1984). T-Stellate cells have been shown to exhibit CMR in their spike trains, and this sensitivity can be explained by a simple circuit consisting of a wideband inhibitory input (such as from D-stellate cells) that converges onto cells receiving narrowband excitation from the AN (Pressnitzer et al., 2001).

To test whether fast inhibition onto T-stellate cells is necessary for CMR, we implemented a network model of the CN (see Materials and Methods) to test whether the brief time course of inhibition in T-stellate cells is critical for CMR. Sound stimuli under three conditions (REF, CM, and CD, as shown in Fig. 10A1-C1) were presented to a model of the cochlea and AN (Zilany et al., 2009) to generate spike trains. These spike trains activated AN terminals in the VCN network (Fig. 10D). Inhibitory interneurons, representing D-stellate cells, received input from a wide range of AN fibers and provided inhibition to a bank of target T-stellate cells. Signal detectability was probed by comparing spike trains in responses to stimuli with and without the on-frequency signal (Fig. $10 A-C$ ), and a $d^{\prime}$ statistic was computed as described previously (Pressnitzer et al., 2001) (see Materials and Methods). Larger $d^{\prime}$ values imply greater detectability of the signal.

The poststimulus time histograms (PSTHs) in Figure 10, A2 and $A 3$, compare responses to equal signal/masker ratios for the REF condition (Fig. 10A2) with the response to the on-frequency masker alone (Fig. 10A3). In the presence of the masker, it is difficult to identify the signal at all as shown in Figure $10 \mathrm{~A} 2$. However, in the CM condition, the off-frequency comodulated components drive the inhibitory cell and suppress the response to the on-frequency masker (Fig. 10B3) while not suppressing the response to the signal (Fig. 10B2); thus, the signal stands out. In the $\mathrm{CD}$ condition, there is a strong response during a portion of the on-frequency masker in the absence of the on-frequency signal (Fig. 10, compare C3, C1), but the addition of the onfrequency signal fails to elicit any additional spikes (Fig. 10C2).

The detectability of the signal over a range of signal/masker ratios is summarized in Figure 10E. With fast inhibition, the sig- 


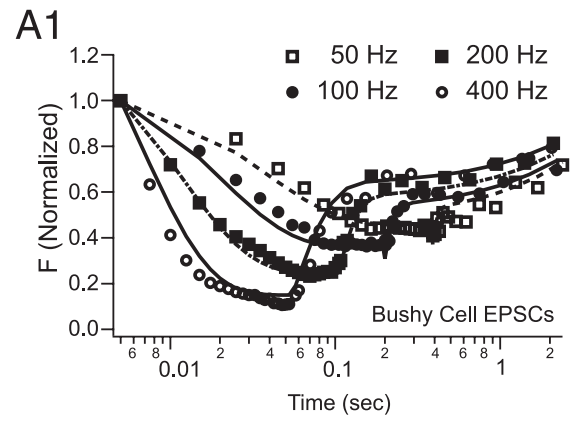

A2
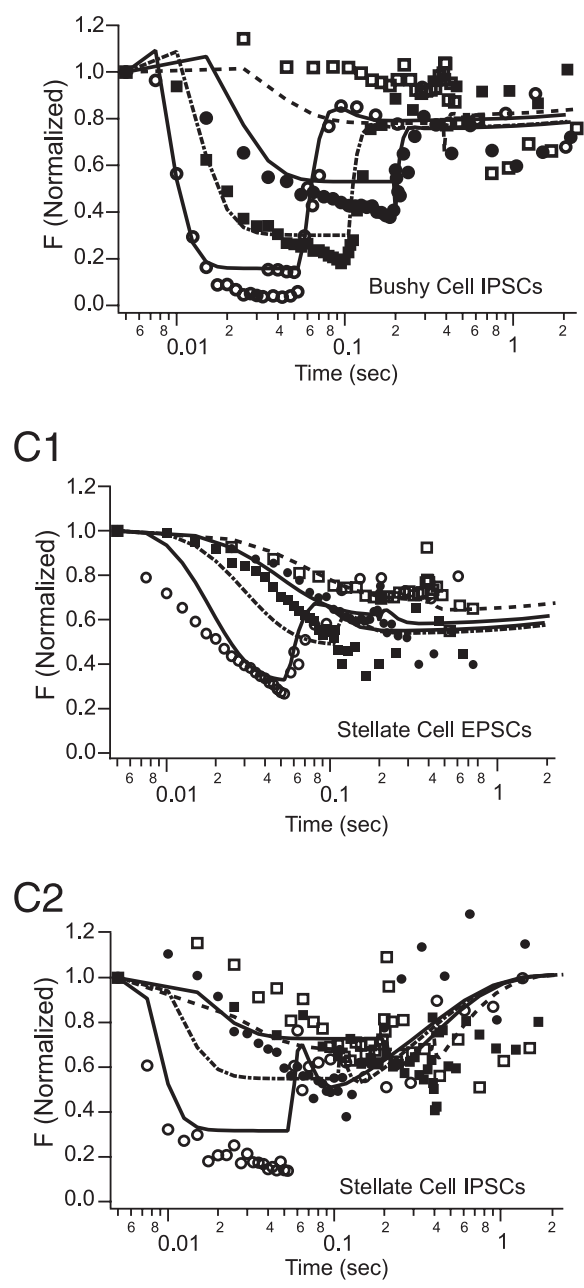

B1

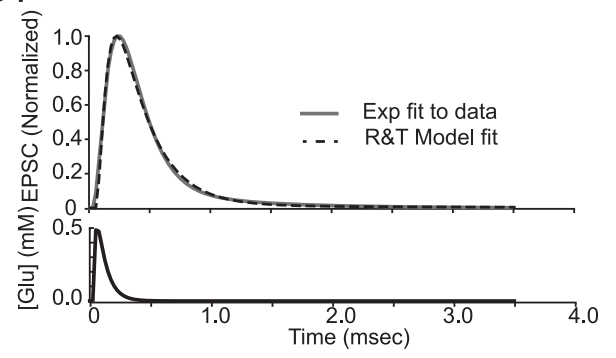

B2
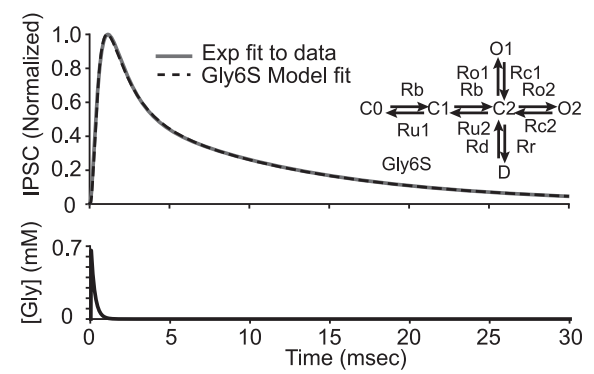

D1

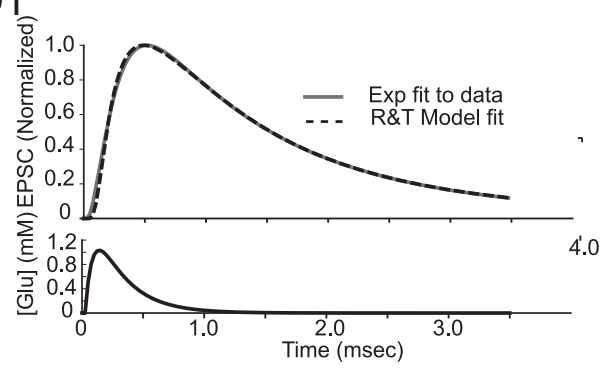

D2

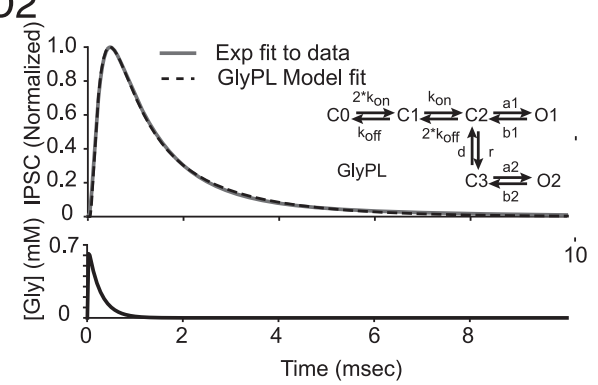

E

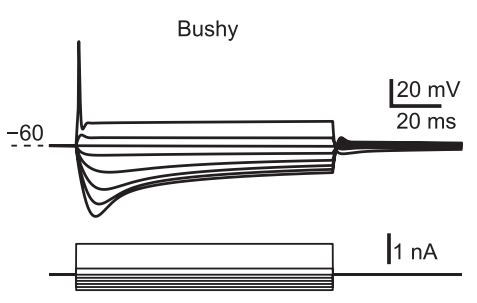

F
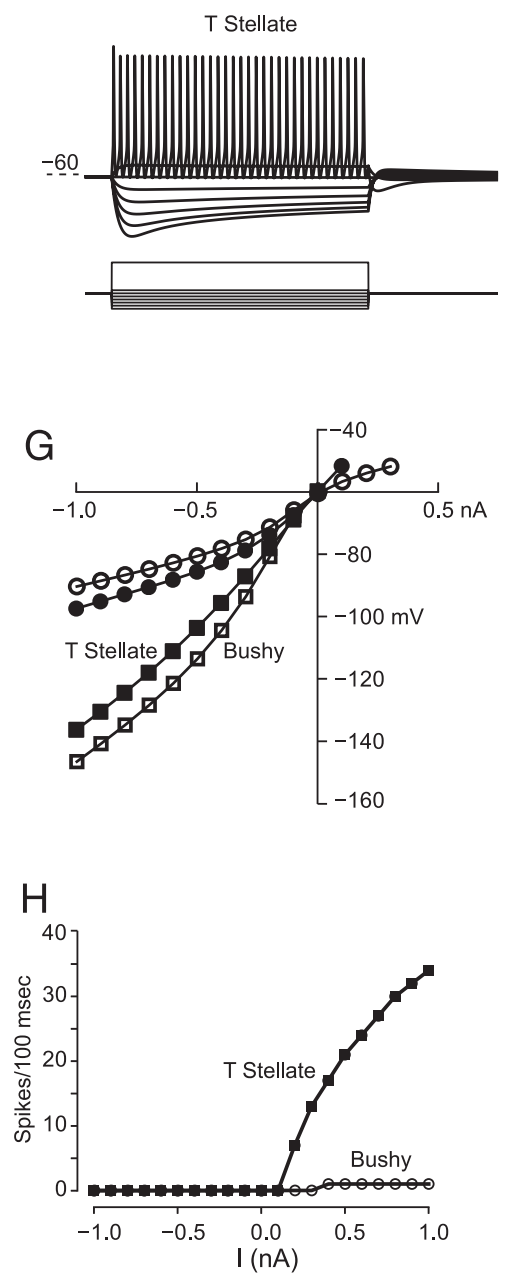

Figure 8. Cellular and network models for bushy and T-stellate cells.A1, Example of rate-dependent depression and recovery for AN EPSCs in a bushy cell. Symbols, The time course of the release probability, $P_{\mathrm{r}}=F(t) \times D(t) \times F_{1}$, where $F(t)$ is the facilitation term as a function of time $[F(0)=1.0], D(t)$ is the depression term $[D(0)=1.0]$, and $F_{1}$ is the initial value that sets the release probability (from Table 1 ) of bushy cell EPSCs in response to stimulation of the AN. The lines are simultaneous fits of the kinetic model for all frequencies and time points for an individual cell. $A 2$, Example of rate-dependent depression and recovery for TBV tract elPSCs in a bushy cell. Lines indicate fits as in A1. B1, Fit of state models for bushy cell EPSCs to the time course of synaptic currents. Top axes, The "Exp fit to data" is from Equation 3, using the parameters in Table 3. The dashed line is the fit to the state model of Raman and Trussell (1992) (R\&T Model fit), with the parameters given in Table 2. Bottom axes, Time course of the synaptic cleft glutamate transient associated with the fit. A2, The time course of bushy cell IPSCs was best fit by a six-state model with two open states. Inset, Six-state model (Gly6S). Top axes, The solid line ("Exp fit to data") is from Equation 3, using the parameters in Table 3. The dashed line is from the model, with the parameters shown in Table 4. Bottom axes, Time course of the synaptic cleft glycine transient, estimated using Equation 1. C1, C2, The time course and fits of release probability for T-stellate cell EPSCS (C1) and IPSCS (C2) in the same layout as in $\boldsymbol{A 1}$ and $\boldsymbol{A 2}$. The kinetic parameters are listed in Table 1.D1, D2, Fits of state model for T-stellate cell EPSCS (D1) and IPSCs (D2). The panels are in the same layout as in B1 and B2, with the parameters given in Tables 2-4. For details of the fitting procedures, see Materials and Methods. $\boldsymbol{E}$, , Response of the bushy and T-stellate model cells (mouse parameters) to current injections, respectively. G, Current-voltage relationships of bushy and T-stellate cell model. Open symbols, Bushy cell; filled symbols, T-stellate cell; circles, steady-state voltage; squares, peak voltage. $\boldsymbol{H}$, Firing rates of bushy and T-stellate cell model to current injections. Open symbols, Bushy cell model; filled squares, T-stellate cell model.

nal detectability increased moderately with increasing signal/ masker ratios under the REF condition, was the largest in the CM condition, but showed little change in the CD condition. The $d^{\prime}$ for the CM condition increased significantly over the REF condi- tion for signal/masker ratios above $0 \mathrm{~dB}$ and was greater than the $\mathrm{CD}$ condition for signal/masker ratios above $-15 \mathrm{~dB}$. However, when the time course of the inhibition onto the T-stellate cell model was slowed to that seen in bushy cells $(\tau=11 \mathrm{~ms}$; Fig. 

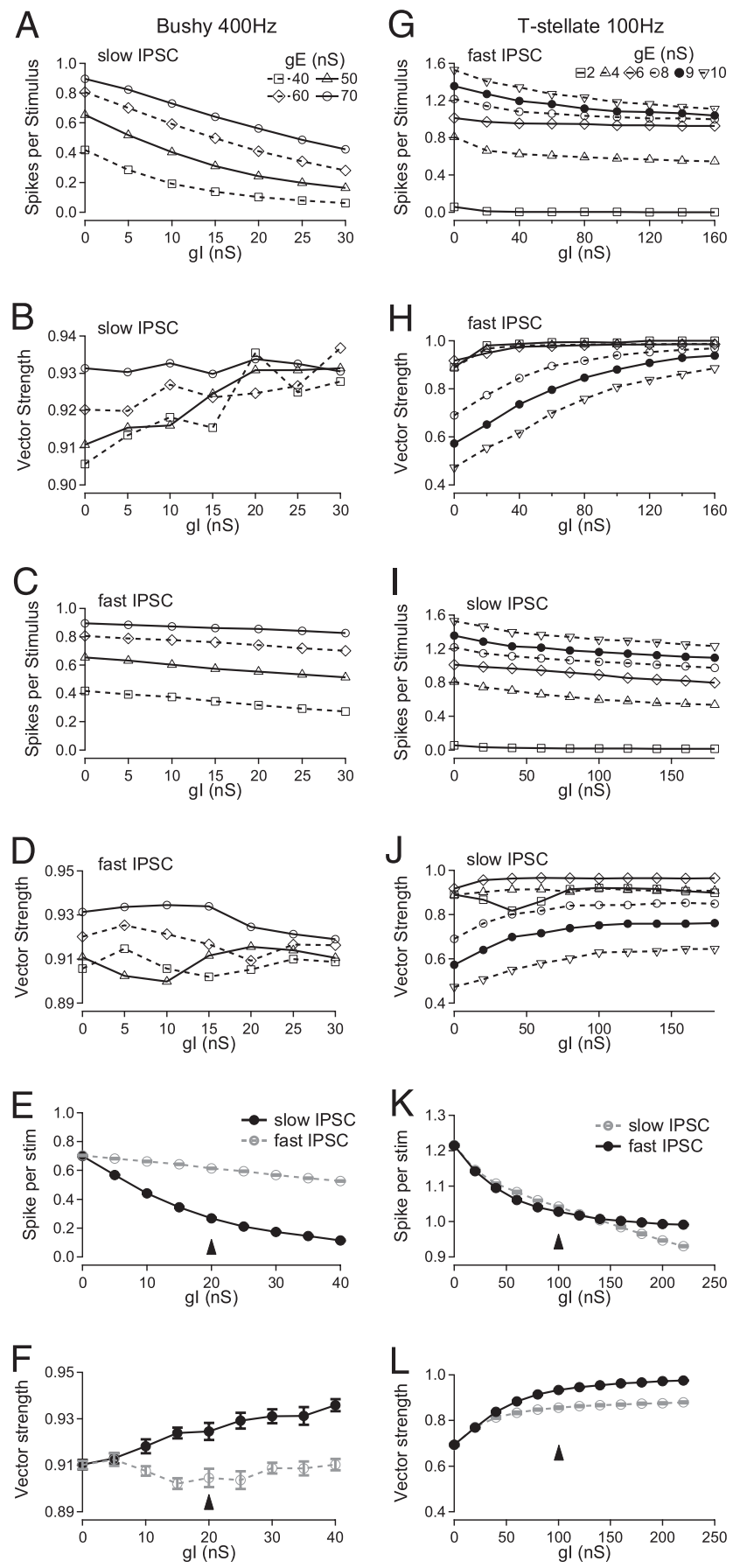

Figure 9. IPSC kinetics control temporal precision in simulated bushy and T-stellate cells. $\boldsymbol{A}$, Parametric exploration of firing probability in bushy cell model for different combinations of excitatory (same symbols as in $\boldsymbol{B}$ ) and inhibitory (abscissa) conductance levels for $400 \mathrm{~Hz}$ stimulus trains. Slow inhibition ( $\tau=11 \mathrm{~ms}$ ) as observed experimentally in bushy cells was used. Spike probability was used to choose parameters shown in model simulation in Figure 5. $\boldsymbol{B}$, Vector strength across the same parameter space as in $\boldsymbol{A}$. C, Similar to $\boldsymbol{A}$ but using fast IPSC time course ( $\tau=1.3 \mathrm{~ms}$ ) observed in T-stellate cells, in the bushy cell model. $\boldsymbol{D}$, Vector strength across the same parameter space as in $\boldsymbol{C} . \boldsymbol{E}, \boldsymbol{F}$, Firing probability and vector strength of the bushy cell model in response to 50 -pulse stimulation at $400 \mathrm{~Hz}$ with either slow or fast IPSCs. Excitatory conductance used: $g_{\mathrm{E}}=50 \mathrm{nS}$. Arrowhead, The selected conductance levels used in Figure 5/- $L$. G, Parametric exploration of firing probability in T-stellate cell model for different combinations of excitatory (symbols as in $\boldsymbol{H}$ ) and inhibitory (abscissa) conductance levels for $100 \mathrm{~Hz}$ stimulus trains. Fast inhibition ( $\tau=1.3 \mathrm{~ms}$ ) observed experimentally in T-stellate cells was used. Spike probability was used to choose parameters shown in model simulations in Figure 6 . $\boldsymbol{H}$, Vector strength across the same parameter space as in $\boldsymbol{G}$. $\boldsymbol{I}, \boldsymbol{J}$, Same as in $\boldsymbol{G}, \boldsymbol{H}$, except slow inhibition ( $\tau=11 \mathrm{~ms}$ ) was used. $\boldsymbol{K}, \boldsymbol{L}$, Firing probability and vector strength of the T-stellate model in response to 50 -pulse stimulation at $100 \mathrm{~Hz}$ with slow or fast IPSCS. Excitatory conductance used:
$10 F)$, the CM and CD conditions were equivalent, and the signal detectability was poor at all signal/masker ratios. Thus, with slow inhibition, there was no release from masking at any signal/ masker ratio.

We then evaluated signal detectability as a function of the IPSC decay time constant at $0 \mathrm{~dB}$ signal/masker ratio. Remarkably, detection of the signal was better in the CM condition than the REF condition only when the IPSC decay time constant is less than $\sim 2.5 \mathrm{~ms}$ (Fig. $10 G$ ). Signal detectability is better than the CD condition for IPSCs faster than $\sim 4.0 \mathrm{~ms}$. These results suggest that fast inhibition onto T-stellate cells is critical for detecting narrowband signals in complex wideband acoustic environments.

To gain insight into how the rapid decay of IPSPs contributes to the masking release, we examined the time course of synaptic currents during responses to the CMR stimuli (Fig. 11). The excitatory input follows the expected pattern, in which EPSPs occur during both the modulation periods of the on-frequency masker and the signal. With inhibitory inputs that decay rapidly (Fig. $11 \mathrm{~A}, 1.3 \mathrm{~ms})$, the inhibition from the D-stellate cells is strong during the crest of the maskers but rapidly decays when the masker modulation is at a minimum. At this time, the cell is released from inhibition and can respond to the on-frequency signal, which is generating EPSPs. However, when the inhibition time course is slow (Fig. 11C, $11 \mathrm{~ms}$ ), inhibition does not completely decay during the valleys. As a result, the cell fails to show a strong differential response to the EPSPs of the on-frequency signal, which are subject to the residual inhibition from the previous modulation cycle. These simulations suggest that the CMR depends on a transient imbalance between inhibition and excitation that occurs because the fast inhibition does not carry over into the masker valleys, allowing the excitation to drive the cell in response to the on-frequency signal.

We also tested whether bushy cells showed a similar CMR effect in the model by replacing the model T-stellate cells with model bushy cells. The presence of comodulated flanking sidebands in model bushy cells did not improve signal detection relative to the REF condition, independent of the IPSC decay time course (Fig. 12). Codeviant flanking sidebands reduced detectability of the signal at all signal/masker ratios. These results are consistent with previous physiological observations that, although CMR can be detected in some bushy cells, it is not as prevalent as in stellate cells (Pressnitzer et al., 2001). The lack of a difference between the REF and CM conditions, regardless of the decay rate of inhibition, appears to result from two related factors. First, the modeling results suggest that the strong AN excitation in bushy cells overpowers the weaker wideband inhibition during both the masker and any residual inhibition occurring in the dips of the masker, regardless of the IPSP decay time course, leading to spiking and detection of the on-frequency signal. Second, the $d^{\prime}$ values from the bushy cell model for both the REF and $\mathrm{CM}$ conditions are larger than those observed in the T-stellate model under any conditions, which suggests that a ceiling effect may be present that prevents additional improvements in detectability of the signal.

$\leftarrow$

$g_{\mathrm{E}}=8 \mathrm{nS}$. The arrowhead marks the conductance levels used in Figure 6D-G. Data are the mean and SEM of 10 independent runs of the model, using different seeds for the stochastic processes of transmitter release latency and release probability. SEs in $\boldsymbol{E}$ and $\boldsymbol{K}$ are small and masked by data symbols. 

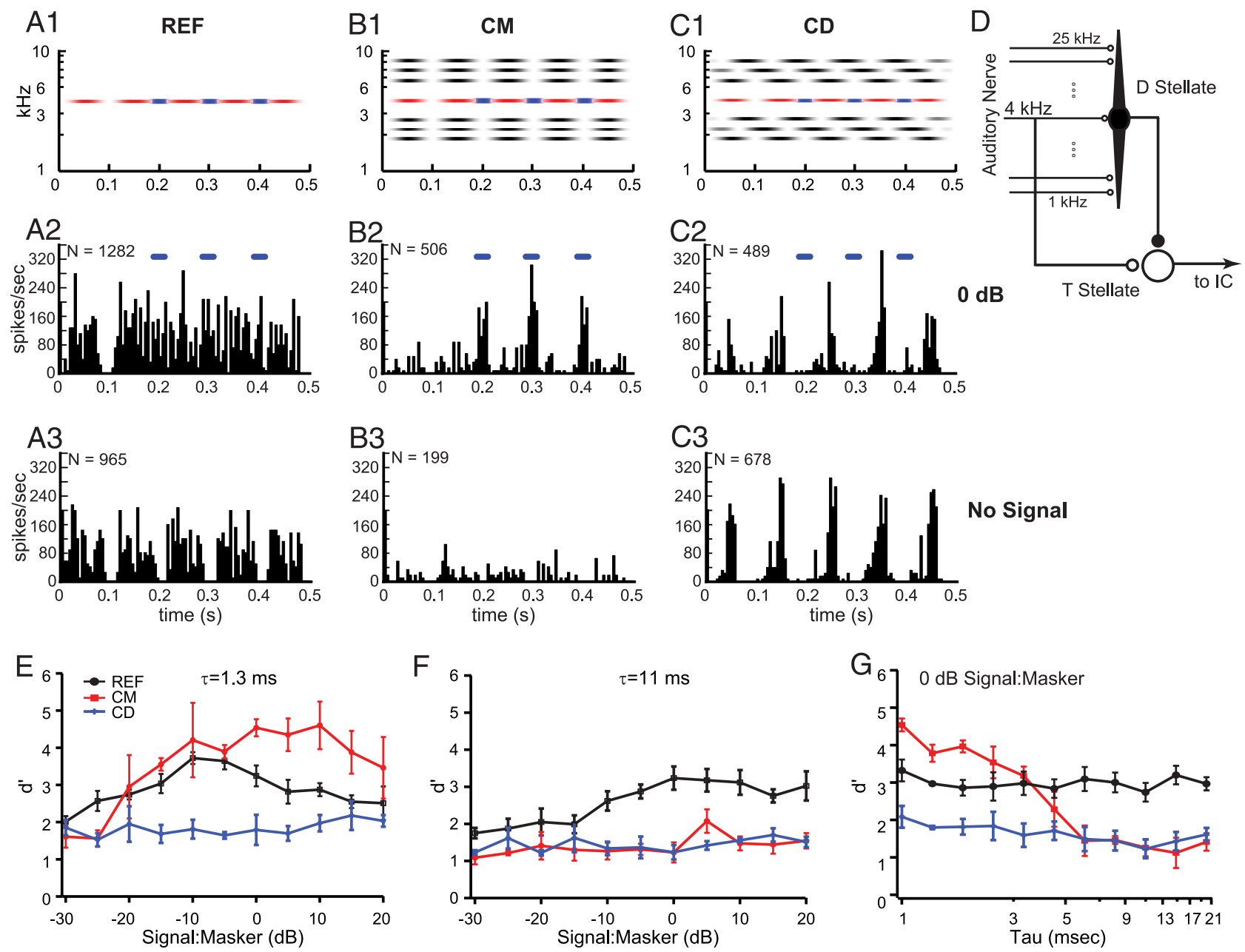

Figure 10. Fast inhibition is required for T-stellate cells to exhibit CMR. $\mathbf{A 1}$, Spectrogram of the REF stimulus, consisting of a masker (red) and a signal (blue), each amplitude modulated at $10 \mathrm{~Hz}$. A2, PSTHs (5 ms bin width) showing responses in one trial across 25 T-stellate cells. Blue bars indicate timing of the signal. A3, PSTH with no signal. The signal elicits spikes (A2) during minima in the masker (A3). Ordinate spike rate is normalized per cell. $n=$ total spike count. B1, Spectrogram for the CM condition. B2, PSTH as in A2. The cells fire primarily during the signal. $\boldsymbol{B}$ 3, PSTH during CM condition with no signal. C1, CD condition, in which the flanking sidebands are not phase coherent with the masker. C2, PSTH of CD condition as in A2. C3, PSTH of CD condition with no signal. The cells fire primarily during the masker in both $\mathbf{C}$ and $\mathbf{C}$. D. Network schematic showing wideband AN inputs to the inhibitory D-stellate cell and on-frequency excitatory AN input to the target bushy or T-stellate cell. Synapses are marked with either open (excitatory) or filled (inhibitory) symbols. IC, Inferior colliculus. E, Detectability ( $d^{\prime}$ ) of the signal with changes in signal/masker ratio, for fast inhibition. CMR (relative to the CD condition) occurs for signal/masker ratios greater than $-15 \mathrm{~dB}$. Error bars are SDs of four runs with different random draws of network connectivity. $\boldsymbol{F}$, Detectability, as in $\boldsymbol{E}$ with slow inhibition. The CM sounds fail to improve detectability of the signal. G, Detectability is best with fast IPSCs. For model details, see Materials and Methods.

\section{Discussion}

We have shown how glycinergic inhibition plays critical roles in temporal information processing at the first neural station of the central auditory system. In bushy cells, glycinergic IPSCs with slow kinetics generate tonic inhibition that increases the spike threshold, which helps improve spike precision on a timescale of tens of microseconds, thus enhancing the fine temporal coding of the auditory information (Oertel, 1999). IPSCs in T-stellate cells are eight times faster than those in bushy cells and convey a rapid and transient inhibition, which does not affect spike threshold but counteracts the slow NMDA currents. This inhibition eliminates poorly timed spikes, resulting in improved spike timing on a millisecond timescale. Although the improvement in spike timing for T-stellate cells is on a slower timescale than in bushy cells, it is suitable for encoding envelope cues. Our models demonstrate that the differences in IPSC time courses are essential for neural processing in both cell types, because using fast inhibition in bushy cells or slow inhibition in T-stellate cells is predicted to impair the temporal precision of spikes relative to that seen with native IPSC time courses. Moreover, in T-stellate cells, only
IPSCs with decay time constants $<2.5 \mathrm{~ms}$ can improve signal detection in the presence of modulated maskers in the VCN network model. Our findings suggest that the specific kinetics of glycinergic inhibition play an essential role in the processing of temporal information in the CN. Given that IPSCs with diverse kinetics are widely observed elsewhere in the nervous system, with decay time courses varying from a few milliseconds (Awatramani et al., 2004; Magnusson et al., 2005; Graham et al., 2006; Beato, 2008; Wässle et al., 2009) to tens of milliseconds (Takahashi et al., 1992; Veruki et al., 2007; Balakrishnan and Trussell, 2008; Wässle et al., 2009), target-specific IPSC kinetics may serve as a common mechanism tailored to the unique physiological processing roles of different neurons.

Neural computation relies on the spatial and temporal interplay of inhibitory and excitatory inputs as well as the nonlinearity of voltage-dependent conductances. The IPSC time courses that we have measured are members of a constellation of mechanisms that distinguish cell types that process different aspects of the acoustic environment in the VCN. Bushy cells have a short membrane time constant and high membrane conductance that results from low- 

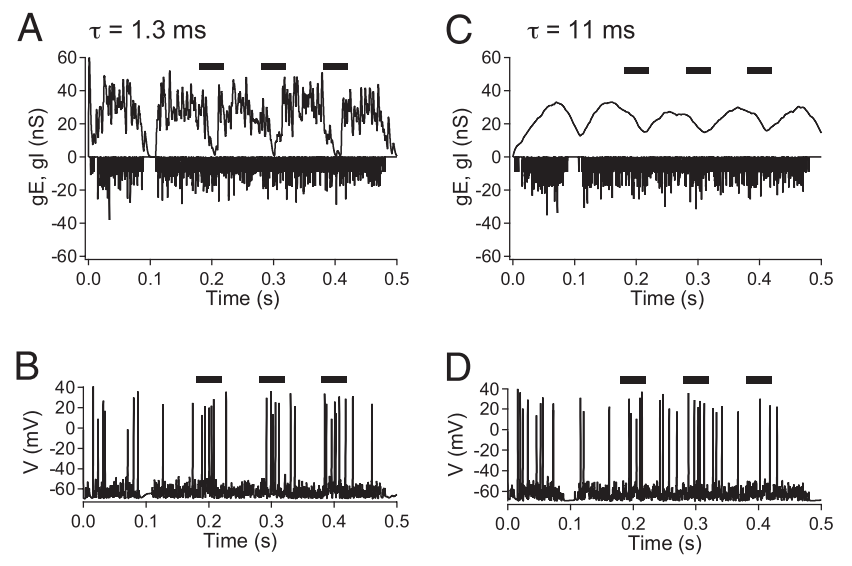

Figure 11. Excitatory and inhibitory synaptic conductances during CMR as measured in T-stellate cell model. Data are shown for the CMR condition with a signal/masker ratio of $0 \mathrm{~dB}$ with $10 \mathrm{~Hz}$ modulation, as in Figure 10. $A$, Fast inhibition is driven by the off-frequency signals but it ceases rapidly in the valleys during the on-frequency signal (indicated by bars above the traces). The positive-going waveform is the total inhibitory conductance to the cell. The negative-going waveform is the total excitatory conductance to the cell. $\boldsymbol{B}$, Cell spiking pattern for the trial shown in $\boldsymbol{A}$ shows firing increases during the release in inhibition, reflecting the drive from the on-frequency signal. $\boldsymbol{C}$, Same format as $\boldsymbol{A}$ but with the fast inhibition replaced by slowly decaying inhibition. Although modulated by the off-frequency signals, the inhibition does not fully decay between cycles of the masker. $\boldsymbol{D}$, Same format as $\boldsymbol{B}$ except with slow inhibition. Although the firing rate is modulated by the masker, the release during the signal is less clearly timed to the signal, and detection of the on-frequency signal is impaired.
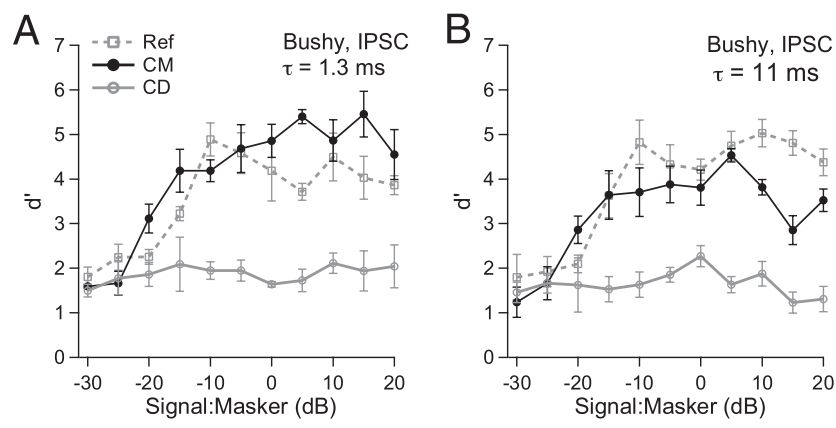

Figure 12. Kinetics of IPSCS do not affect CMR in bushy cell model. Detectability of onfrequency signals in the presence of an on-frequency masker and flanking sidebands (same as in Fig. 10A1,B1,C1), for different signal/masker ratios, for model bushy cells. Although the flaking bands provide little improvement in detection for either fast or slow IPSCs relative to the REF condition, the signals are significantly masked in the presence of codeviant flanking bands. $A$, Using fast inhibition; $\boldsymbol{B}$, using slow inhibition. Error bars are SDs.

voltage-activated potassium (Rothman and Manis, 2003a; Cao et al., 2007) and $I_{\mathrm{h}}$ (Cao et al., 2007) channels. The specialized AN synapses onto bushy cells, the end bulbs of Held (Manis et al., 2011), produce exceptionally large and brief conductance changes, which help preserve the timing of spikes that report phase information used for binaural localization and pitch judgments. Slow IPSPs that summate can limit spike generation to the largest and fastest-rising EPSPs (Fig. 7) and thus contribute to improvements in spike timing. In contrast to bushy cells, T-stellate cells have a slower membrane time constant and higher resting input resistance, so that excitatory inputs generate larger and longer-lasting EPSPs. The higher input resistance also allows fast inhibition to significantly influence the membrane potential and transiently interact with EPSPs to regulate firing. The integrated roles of inhibitory kinetics, cell-specific excitatory strength, and intrinsic membrane conductances are supported by results from our cellular and network models. A related, but mechanistically distinct, interaction is present in bushy cells of the avian nucleus mag- nocellularis, which receive slow depolarizing GABAergic IPSCs that help improve temporal processing by increasing activation of the low-voltage-activated potassium conductance (Monsivais et al., 2000). In contrast, neurons in the medial superior olive, which receive balanced excitatory and inhibitory inputs and which exhibit much lower input resistances than bushy cells (Couchman et al., 2010), receive fast IPSCs that might help encode microsecond interaural time differences (Smith et al., 2000; Brand et al., 2002; Magnusson et al., 2005) (but for a different interpretation, see Joris and Yin, 2007). Therefore, the contribution of target-specific inhibitory kinetics also depends on the complement of cell-specific excitatory inputs and intrinsic properties.

Although the inhibition is primarily tonic in bushy cells, it shifts from being phasic at $100 \mathrm{~Hz}$ to tonic at $400 \mathrm{~Hz}$ in T-stellate cells. In both cell types, the sustained firing rate for excitatory inputs (AN fibers) and inhibitory inputs (TBV cells and D-stellate cells) can range from near $0 \mathrm{~Hz}$ to $>400 \mathrm{~Hz}$ during acoustic stimulation. Our results suggest that temporal processing in bushy cells is improved most when the inhibitory inputs are firing at high frequencies. In T-stellate cells, entrainment to repetitive stimulation is improved when the inhibitory inputs are firing in synchrony with excitation at lower rates. However, dynamic acoustic events can result in transient high rates of firing of the inhibitory interneurons. Such periods of high-frequency activity would result in brief periods of summation, followed by a rapid decay when the inhibition terminates. It is likely that this pattern is partially what underlies the CMR sensitivity of T-stellate cells (Fig. 11).

Natural acoustic environments contain many time-varying broadband sounds, such as produced by the wind passing through leaves and grasses, as well as modulated sounds containing narrowband components typical of conspecific acoustic communication signals (Lewicki, 2002; Singh and Theunissen, 2003). CMR, which has been demonstrated in avians, rodents, and dolphins and humans (Hall et al., 1984; Klump and Langemann, 1995; Branstetter and Finneran, 2008; Klink et al., 2010), allows detection of narrowband sounds in the presence of such natural wideband fluctuating maskers. The need for fast inhibition in the stellate cell pathway has not been obvious, although several models have used brief inhibition to investigate the integrative properties of VCN stellate cells (Banks and Sachs, 1991; Lai et al., 1994; Wang and Sachs, 1995). Conversely, studies with iontophoresis of inhibitory receptor antagonists suggest that a time-invariant inhibition onto stellate cells is sufficient to explain their responses to narrowband sounds and does not affect the processing of signals in the presence of unmodulated wideband noise (Gai and Carney, 2008). Our modeling shows that fast inhibition is necessary for CMR, although the fluctuation frequency is low $(10 \mathrm{~Hz})$. CMR can also be observed for fluctuating maskers up to $>100 \mathrm{~Hz}$ (Carlyon et al., 1989; Eddins and Wright, 1994). In the model, we detected CMR at 10, 20, and $50 \mathrm{~Hz}$ but not $100 \mathrm{~Hz}$ (data not shown). We suggest, based on the time course of inhibition during the CMR condition (Fig. 11), that when the masking signal terminates, the inhibition quickly ceases, leaving the cells responsive to sounds within their narrow excitatory area. In this way, the fast inhibition helps generate temporal contrast between broadband and narrowband sounds.

Glycinergic IPSC kinetics are governed mainly by the receptor $\alpha$ subunits (Lynch, 2009; Wässle et al., 2009) but can also be modified by synchronization of transmitter release (Magnusson et al., 2005), transmitter pooling at the cleft (Balakrishnan et al., 2009), cotransmission of GABA and glycine (Lu et al., 2008), phosphorylation or dephosphorylation of receptors (Gentet and Clements, 2002), or changes in the internal concentration of chloride in the postsynaptic cell (Pitt et al., 2008). The diversity of 
receptor subunits, combined with the numerous posttranslational mechanisms that can modify glycinergic transmission, can provide highly regulated, target-specific IPSC kinetics that fit the functional needs of individual neurons. In the VCN, we found that the decay time courses of eIPSCs and sIPSCs within either bushy or T-stellate cells were similar, which suggests that the cells mainly express one combination of glycine receptor subunits at all synapses, regardless of the sources of afferent terminals. Our estimates of single-channel conductances and the sIPSC decay time constants in T-stellate and bushy cells are consistent with those of the $\alpha 1 \beta$ and $\alpha 2 \beta$ isoforms of the glycinergic receptor found in retinal neurons, respectively (Gill et al., 2006; Veruki et al., 2007; Wässle et al., 2009), after adjusting for temperature differences assuming a $Q_{10}$ of 2.1 (Smith et al., 2000). Posttranslational mechanisms may also contribute to receptor kinetics diversity within a cell population but seem unlikely to be the sole basis of the large difference in kinetics between bushy and $\mathrm{T}$-stellate cells. It has been widely observed that, in other regions of the nervous system, glycinergic receptors composed of $\alpha 2 \beta$ subunits are abundant early in development and, with maturation, gradually switch to the adult $\alpha 1 \beta$ isoform. The trend is not always true in all neural circuits (Lynch, 2009). Our study suggests that such a switch might occur in T-stellate cells during development and might not occur in bushy cells, which would be consistent with the continued presence of $\alpha 2$ mRNA in the AVCN through adulthood (Piechotta et al., 2001).

In summary, parallel processing is a fundamental feature of central sensory information processing and is especially prominent in the central auditory system, in which different aspects of the acoustic waveform are processed through separate neural pathways before converging in higher nuclei. These pathways are initiated at the level of the CN (Cant and Benson, 2003), through populations of cells that receive specialized excitatory synapses and express particular complements of ion channels. Our findings reveal that, at this first integrative step in the $\mathrm{CN}$, the targetspecific time course of glycinergic inhibition is yet another neural mechanism that contributes to the parallel processing of auditory information in the time domain.

\section{References}

Altschuler RA, Betz H, Parakkal MH, Reeks KA, Wenthold RJ (1986) Identification of glycinergic synapses in the cochlear nucleus through immunocytochemical localization of the postsynaptic receptor. Brain Res 369: 316-320. CrossRef Medline

Arnott RH, Wallace MN, Shackleton TM, Palmer AR (2004) Onset neurones in the anteroventral cochlear nucleus project to the dorsal cochlear nucleus. J Assoc Res Otolaryngol 5:153-170. CrossRef Medline

Awatramani GB, Turecek R, Trussell LO (2004) Inhibitory control at a synaptic relay. J Neurosci 24:2643-2647. CrossRef Medline

Balakrishnan V, Trussell LO (2008) Synaptic inputs to granule cells of the dorsal cochlear nucleus. J Neurophysiol 99:208-219. CrossRef Medline

Balakrishnan V, Kuo SP, Roberts PD, Trussell LO (2009) Slow glycinergic transmission mediated by transmitter pooling. Nat Neurosci 12:286-294. CrossRef Medline

Banks MI, Sachs MB (1991) Regularity analysis in a compartmental model of chopper units in the anteroventral cochlear nucleus. J Neurophysiol 65:606-629. Medline

Barela AJ, Waddy SP, Lickfett JG, Hunter J, Anido A, Helmers SL, Goldin AL, Escayg A (2006) An epilepsy mutation in the sodium channel SCN1A that decreases channel excitability. J Neurosci 26:2714-2723. CrossRef Medline

Beato M (2008) The time course of transmitter at glycinergic synapses onto motoneurons. J Neurosci 28:7412-7425. CrossRef Medline

Betz H, Gomeza J, Armsen W, Scholze P, Eulenburg V (2006) Glycine transporters: essential regulators of synaptic transmission. Biochem Soc Trans 34:55-58. CrossRef Medline
Brand A, Behrend O, Marquardt T, McAlpine D, Grothe B (2002) Precise inhibition is essential for microsecond interaural time difference coding. Nature 417:543-547. CrossRef Medline

Branstetter BK, Finneran JJ (2008) Comodulation masking release in bottlenose dolphins (Tursiops truncatus). J Acoust Soc Am 124:625-633. CrossRef Medline

Cant NB, Benson CG (2003) Parallel auditory pathways: projection patterns of the different neuronal populations in the dorsal and ventral cochlear nuclei. Brain Res Bull 60:457-474. CrossRef Medline

Cao XJ, Oertel D (2010) Auditory nerve fibers excite targets through synapses that vary in convergence, strength, and short-term plasticity. J Neurophysiol 104:2308-2320. CrossRef Medline

Cao XJ, Shatadal S, Oertel D (2007) Voltage-sensitive conductances of bushy cells of the mammalian ventral cochlear nucleus. J Neurophysiol 97:3961-3975. CrossRef Medline

Carlyon RP, Buus S, Florentine M (1989) Comodulation masking release for three types of modulator as a function of modulation rate. Hear Res 42:37-45. CrossRef Medline

Caspary DM, Backoff PM, Finlayson PG, Palombi PS (1994) Inhibitory inputs modulate discharge rate within frequency receptive fields of anteroventral cochlear nucleus neurons. J Neurophysiol 72:2124-2133. Medline

Clements JD, Bekkers JM (1997) Detection of spontaneous synaptic events with an optimally scaled template. Biophys J 73:220-229. CrossRef Medline

Couchman K, Grothe B, Felmy F (2010) Medial superior olivary neurons receive surprisingly few excitatory and inhibitory inputs with balanced strength and short-term dynamics. J Neurosci 30:17111-17121. CrossRef Medline

Dittman JS, Kreitzer AC, Regehr WG (2000) Interplay between facilitation, depression, and residual calcium at three presynaptic terminals. J Neurosci 20:1374-1385. Medline

Eddins DA, Wright BA (1994) Comodulation masking release for single and multiple rates of envelope fluctuation. J Acoust Soc Am 96:3432-3442. CrossRef Medline

Elhilali M, Ma L, Micheyl C, Oxenham AJ, Shamma SA (2009) Temporal coherence in the perceptual organization and cortical representation of auditory scenes. Neuron 61:317-329. CrossRef Medline

Ferragamo MJ, Golding NL, Oertel D (1998) Synaptic inputs to stellate cells in the ventral cochlear nucleus. J Neurophysiol 79:51-63. Medline

Francis HW, Manis PB (2000) Effects of deafferentation on the electrophysiology of ventral cochlear nucleus neurons. Hear Res 149:91-105. CrossRef Medline

Fujino K, Oertel D (2001) Cholinergic modulation of stellate cells in the mammalian ventral cochlear nucleus. J Neurosci 21:7372-7383. Medline

Gai Y, Carney LH (2008) Influence of inhibitory inputs on rate and timing of responses in the anteroventral cochlear nucleus. J Neurophysiol 99: 1077-1095. CrossRef Medline

Gardner SM, Trussell LO, Oertel D (2001) Correlation of AMPA receptor subunit composition with synaptic input in the mammalian cochlear nuclei. J Neurosci 21:7428-7437. Medline

Gentet LJ, Clements JD (2002) Binding site stoichiometry and the effects of phosphorylation on human alphal homomeric glycine receptors. J Physiol 544:97-106. CrossRef Medline

Gill SB, Veruki ML, Hartveit E (2006) Functional properties of spontaneous IPSCs and glycine receptors in rod amacrine (AII) cells in the rat retina. J Physiol 575:739-759. CrossRef Medline

Goldberg JM, Brown PB (1969) Response of binaural neurons of dog superior olivary complex to dichotic tonal stimuli: some physiological mechanisms of sound localization. J Neurophysiol 32:613-636. Medline

Goodman DF, Brette R (2009) The brian simulator. Front Neurosci 3:192-197. CrossRef Medline

Graham BA, Schofield PR, Sah P, Margrie TW, Callister RJ (2006) Distinct physiological mechanisms underlie altered glycinergic synaptic transmission in the murine mutants spastic, spasmodic, and oscillator. J Neurosci 26:4880-4890. CrossRef Medline

Grose JH, Hall JW 3rd (1989) Comodulation masking release using SAM tonal complex maskers: effects of modulation depth and signal position. J Acoust Soc Am 85:1276-1284. CrossRef Medline

Hall JW, Haggard MP, Fernandes MA (1984) Detection in noise by spectrotemporal pattern analysis. J Acoust Soc Am 76:50-56. CrossRef Medline

Hartveit E, Veruki ML (2007) Studying properties of neurotransmitter receptors by non-stationary noise analysis of spontaneous postsynaptic cur- 
rents and agonist-evoked responses in outside-out patches. Nat Protoc 2:434-448. CrossRef Medline

Harty TP, Manis PB (1996) Glycine-evoked currents in acutely dissociated neurons of the guinea pig ventral cochlear nucleus. J Neurophysiol 75: 2300-2311. Medline

Isaacson JS, Walmsley B (1995) Counting quanta: direct measurements of transmitter release at a central synapse. Neuron 15:875-884. CrossRef Medline

Joris P, Yin TC (2007) A matter of time: internal delays in binaural processing. Trends Neurosci 30:70-78. CrossRef Medline

Joris PX, Carney LH, Smith PH, Yin TC (1994) Enhancement of neural synchronization in the anteroventral cochlear nucleus. I. Responses to tones at the characteristic frequency. J Neurophysiol 71:1022-1036. Medline

Kampa BM, Clements J, Jonas P, Stuart GJ (2004) Kinetics of $\mathrm{Mg}^{2+}$ unblock of NMDA receptors: implications for spike-timing dependent synaptic plasticity. J Physiol 556:337-345. CrossRef Medline

Klink KB, Dierker H, Beutelmann R, Klump GM (2010) Comodulation masking release determined in the mouse (Mus musculus) using a flanking-band paradigm. J Assoc Res Otolaryngol 11:79-88. CrossRef Medline

Klump GM, Langemann U (1995) Comodulation masking release in a songbird. Hear Res 87:157-164. CrossRef Medline

Korinek M, Sedlacek M, Cais O, Dittert I, Vyklicky L Jr (2010) Temperature dependence of $\mathrm{N}$-methyl-D-aspartate receptor channels and $\mathrm{N}$-methyl-D-aspartate receptor excitatory postsynaptic currents. Neuroscience 165:736-748. CrossRef Medline

Kuenzel T, Borst JG, van der Heijden M (2011) Factors controlling the input-output relationship of spherical bushy cells in the gerbil cochlear nucleus. J Neurosci 31:4260-4273. CrossRef Medline

Lai YC, Winslow RL, Sachs MB (1994) A model of selective processing of auditory-nerve inputs by stellate cells of the antero-ventral cochlear nucleus. J Comput Neurosci 1:167-194. CrossRef Medline

Legendre P (1998) A reluctant gating mode of glycine receptor channels determines the time course of inhibitory miniature synaptic events in zebrafish hindbrain neurons. J Neurosci 18:2856-2870. Medline

Lewicki MS (2002) Efficient coding of natural sounds. Nat Neurosci 5:356363. CrossRef Medline

Lu T, Rubio ME, Trussell LO (2008) Glycinergic transmission shaped by the corelease of GABA in a mammalian auditory synapse. Neuron 57:524-535. CrossRef Medline

Lynch JW (2009) Native glycine receptor subtypes and their physiological roles. Neuropharmacology 56:303-309. CrossRef Medline

Magnusson AK, Kapfer C, Grothe B, Koch U (2005) Maturation of glycinergic inhibition in the gerbil medial superior olive after hearing onset. J Physiol 568:497-512. CrossRef Medline

Manis PB, Marx SO (1991) Outward currents in isolated ventral cochlear nucleus neurons. J Neurosci 11:2865-2880. Medline

Manis PB, Xie R, Wang Y, Marrs GS, Spirou GA (2011) The endbulbs of Held. In: Synaptic mechanisms in the auditory system, pp 61-93. New York: Springer.

McGinley MJ, Oertel D (2006) Rate thresholds determine the precision of temporal integration in principal cells of the ventral cochlear nucleus. Hear Res 216-217:52-63. CrossRef

Monsivais P, Yang L, Rubel EW (2000) GABAergic inhibition in nucleus magnocellularis: implications for phase locking in the avian auditory brainstem. J Neurosci 20:2954-2963. Medline

Oertel D (1983) Synaptic responses and electrical properties of cells in brain slices of the mouse anteroventral cochlear nucleus. J Neurosci 3:2043-2053. Medline

Oertel D (1999) The role of timing in the brain stem auditory nuclei of vertebrates. Annu Rev Physiol 61:497-519. CrossRef Medline

Oertel D, Wright S, Cao XJ, Ferragamo M, Bal R (2011) The multiple functions of T-stellate/multipolar/chopper cells in the ventral cochlear nucleus. Hear Res 276:61-69. CrossRef Medline

Piechotta K, Weth F, Harvey RJ, Friauf E (2001) Localization of rat glycine receptor alpha1 and alpha2 subunit transcripts in the developing auditory brainstem. J Comp Neurol 438:336-352. CrossRef Medline

Pitt SJ, Sivilotti LG, Beato M (2008) High intracellular chloride slows the decay of glycinergic currents. J Neurosci 28:11454-11467. CrossRef Medline

Pressnitzer D, Meddis R, Delahaye R, Winter IM (2001) Physiological cor- relates of comodulation masking release in the mammalian ventral cochlear nucleus. J Neurosci 21:6377-6386. Medline

Raman IM, Trussell LO (1992) The kinetics of the response to glutamate and kainate in neurons of the avian cochlear nucleus. Neuron 9:173-186. CrossRef Medline

Rhode WS (1999) Vertical cell responses to sound in cat dorsal cochlear nucleus. J Neurophysiol 82:1019-1032. Medline

Rhode WS, Greenberg S (1994) Encoding of amplitude modulation in the cochlear nucleus of the cat. J Neurophysiol 71:1797-1825. Medline

Ribrault C, Sekimoto K, Triller A (2011) From the stochasticity of molecular processes to the variability of synaptic transmission. Nat Rev Neurosci 12:375-387. CrossRef Medline

Rodrigues AR, Oertel D (2006) Hyperpolarization-activated currents regulate excitability in stellate cells of the mammalian ventral cochlear nucleus. J Neurophysiol 95:76-87. Medline

Rothman JS, Manis PB (2003a) Differential expression of three distinct potassium currents in the ventral cochlear nucleus. J Neurophysiol 89:3070-3082. CrossRef Medline

Rothman JS, Manis PB (2003b) Kinetic analyses of three distinct potassium conductances in ventral cochlear nucleus neurons. J Neurophysiol 89: 3083-3096. CrossRef Medline

Rothman JS, Manis PB (2003c) The roles potassium currents play in regulating the electrical activity of ventral cochlear nucleus neurons. J Neurophysiol 89:3097-3113. CrossRef Medline

Saint Marie RL, Benson CG, Ostapoff EM, Morest DK (1991) Glycine immunoreactive projections from the dorsal to the anteroventral cochlear nucleus. Hear Res 51:11-28. CrossRef Medline

Shannon RV, Zeng FG, Kamath V, Wygonski J, Ekelid M (1995) Speech recognition with primarily temporal cues. Science 270:303-304. CrossRef Medline

Shofner WP (2008) Representation of the spectral dominance region of pitch in the steady-state temporal discharge patterns of cochlear nucleus units. J Acoust Soc Am 124:3038-3052. CrossRef Medline

Singh NC, Theunissen FE (2003) Modulation spectra of natural sounds and ethological theories of auditory processing. J Acoust Soc Am 114: 3394-3411. CrossRef Medline

Smith AJ, Owens S, Forsythe ID (2000) Characterisation of inhibitory and excitatory postsynaptic currents of the rat medial superior olive. J Physiol 529:681-698. Medline

Smith PH, Rhode WS (1989) Structural and functional properties distinguish two types of multipolar cells in the ventral cochlear nucleus. J Comp Neurol 282:595-616. CrossRef Medline

Spirou GA, Rager J, Manis PB (2005) Convergence of auditory-nerve fiber projections onto globular bushy cells. Neuroscience 136:843-863. CrossRef Medline

Swaminathan J, Heinz MG (2012) Psychophysiological analyses demonstrate the importance of neural envelope coding for speech perception in noise. J Neurosci 32:1747-1756. CrossRef Medline

Takahashi T, Momiyama A, Hirai K, Hishinuma F, Akagi H (1992) Functional correlation of fetal and adult forms of glycine receptors with developmental changes in inhibitory synaptic receptor channels. Neuron 9:1155-1161. CrossRef Medline

Traynelis SF, Silver RA, Cull-Candy SG (1993) Estimated conductance of glutamate receptor channels activated during EPSCs at the cerebellar mossy fiber-granule cell synapse. Neuron 11:279-289. CrossRef Medline

Ulanovsky N, Las L, Farkas D, Nelken I (2004) Multiple time scales of adaptation in auditory cortex neurons. J Neurosci 24:10440-10453. CrossRef Medline

Veruki ML, Gill SB, Hartveit E (2007) Spontaneous IPSCs and glycine receptors with slow kinetics in wide-field amacrine cells in the mature rat retina. J Physiol 581:203-219. CrossRef Medline

Wang X, Sachs MB (1994) Neural encoding of single-formant stimuli in the cat. II. Responses of anteroventral cochlear nucleus units. J Neurophysiol 71:59-78. Medline

Wang X, Sachs MB (1995) Transformation of temporal discharge patterns in a ventral cochlear nucleus stellate cell model: implications for physiological mechanisms. J Neurophysiol 73:1600-1616. Medline

Wang Y, Manis PB (2005) Synaptic transmission at the cochlear nucleus endbulb synapse during age-related hearing loss in mice. J Neurophysiol 94:1814-1824. CrossRef Medline

Wässle H, Heinze L, Ivanova E, Majumdar S, Weiss J, Harvey RJ, Haverkamp 
S (2009) Glycinergic transmission in the mammalian retina. Front Mol Neurosci 2:6. CrossRef Medline

Wickesberg RE, Oertel D (1990) Delayed, frequency-specific inhibition in the cochlear nuclei of mice: a mechanism for monaural echo suppression. J Neurosci 10:1762-1768. Medline

Wu SH, Oertel D (1984) Intracellular injection with horseradish peroxidase of physiologically characterized stellate and bushy cells in slices of mouse anteroventral cochlear nucleus. J Neurosci 4:1577-1588. Medline
Young ED, Voigt HF (1982) Response properties of type II and type III units in dorsal cochlear nucleus. Hear Res 6:153-169. CrossRef Medline

Zilany MS, Bruce IC, Nelson PC, Carney LH (2009) A phenomenological model of the synapse between the inner hair cell and auditory nerve: long-term adaptation with power-law dynamics. J Acoust Soc Am 126: 2390-2412. CrossRef Medline 